\title{
Circular economy in corporate sustainability strategies: A review of corporate sustainability reports in the fast-moving consumer goods sector
}

\author{
Stewart, Raphaëlle Marie Marianne; Niero, Monia
}

Published in:

Business Strategy and the Environment

Link to article, DOI:

10.1002/bse.2048

Publication date:

2018

Document Version

Peer reviewed version

Link back to DTU Orbit

Citation (APA):

Stewart, R. M. M., \& Niero, M. (2018). Circular economy in corporate sustainability strategies: A review of corporate sustainability reports in the fast-moving consumer goods sector. Business Strategy and the Environment, 27(7), 1005-122. https://doi.org/10.1002/bse.2048

\section{General rights}

Copyright and moral rights for the publications made accessible in the public portal are retained by the authors and/or other copyright owners and it is a condition of accessing publications that users recognise and abide by the legal requirements associated with these rights.

- Users may download and print one copy of any publication from the public portal for the purpose of private study or research.

- You may not further distribute the material or use it for any profit-making activity or commercial gain

- You may freely distribute the URL identifying the publication in the public portal 


\section{Circular Economy in corporate sustainability strategies: a review of corporate}

\section{sustainability reports in the Fast-Moving Consumer Goods sector}

\author{
Raphä̈lle Stewart* and Monia Niero*
}

Division for Quantitative Sustainability Assessment, Department of Management Engineering, Technical University of Denmark, Bygningstorvet 115-116B, 2800 Kgs. Lyngby - Denmark

* Corresponding authors.

E-mail addresses: rste@dtu.dk (R. Stewart), monni@dtu.dk (M. Niero)

Keywords: CSR report; sustainable development; packaging; household; food and beverage; textile

\begin{abstract}
:
Despite the increasing interest of business and academic research towards Circular Economy, the investigation of its uptake by industry remains limited. To contribute filling this gap, we perform a systematic review of 46 corporate sustainability reports in the Fast-Moving Consumer Goods sector aiming to explore how companies incorporate the Circular Economy concept in their sustainability agenda. We focus on (i) the companies' uptake of Circular Economy, (ii) the relationship between Circular Economy and sustainability and (iii) the Circular Economy practices presented. Our results show that Circular Economy has started to be integrated into corporate sustainability agenda. Most reported activities are oriented towards the main product and packaging, focusing on end-of-life management and sourcing strategies, and to a lesser extent on circular product design and business model strategies. Most identified collaborations are with businesses, whereas initiatives addressing consumers are largely missing although considered critical for the transition towards Circular Economy.
\end{abstract}




\section{Introduction}

The concept of Circular Economy (CE) provides a central vision within the debate about how society may tackle the increasing resource scarcity and depletion of non-renewable resources. Blomsma \& Brennan (2017) have defined CE under an "umbrella concept", as "an emergent framing around waste and resource management that aims to offer an alternative to prevalent linear take-make-dispose practices by promoting the notion of waste and resource cycling". Since its creation in 2010, the Ellen Mac Arthur Foundation (EMF) has played a key role in bringing CE on the agenda of decision makers, both in the private and public sectors. National and regional strategies for CE have been developed e.g. in China and the European Union (Jones and Comfort, 2017). The body of research around CE is also increasingly gaining ground in the academic literature, where a number of critical reviews have recently investigated the $\mathrm{CE}$ concept, but most studies focused on its origin or theoretical background (Ghisellini et al., 2016; Blomsma and Brennan, 2017; Winans et al., 2017, CIRAIG, 2015, Kirchherr et al. 2017).

The role of businesses in the development of the CE has been emphasized (Lewandowski, 2016) and the interest of companies towards CE has grown over the recent years (Linder and Williamder, 2017). Chinese companies took the lead in CE implementation as a response to the Chinese governmental policy, and applications of $\mathrm{CE}$ in business practice from Western countries are also increasing (Murray et al., 2015). However, only a few studies shed light on CE implementation at the company level, and the implementation of CE worldwide is in its early stages (Ghisellini et al., 2016). Based on a state-ofthe-art review of academic insights into CE, Lieder and Rashid (2016) concluded that in the manufacturing industry CE development is to largest extent done from a resource scarcity and environmental impact perspective disregarding the economic implications. This attitude could be detrimental since the essential activities for a successful CE implementation, such as business models, product design, and choice of material, are in control and hence finally determined by manufacturing companies to gain economic benefits (Lieder and Rashid, 2016).

Recent work has focused on providing support for companies to implement CE at a micro level, i.e. product or organization (Aminoff et al., 2016; Lewandowski, 2016; Pauliuk et al., 2018) and shedding light on the barriers and challenges faced by companies in relation with CE implementation (Linden \& Williander, 2017; Singh and Ordonez, 2016; Ritzen and Sandström, 2017). Other studies deliver insights on best practices and enablers of CE implementation: De los Rios and Charnley (2017) performed an in-depth analysis on case studies from a limited set of multinational enterprises that are transforming their product strategies for closure of material loops, meanwhile Jones and Comfort (2017) presented and discussed the circular approaches of a limited set of companies. Bocken et al. (2017) recently explored the presence of CE thinking in a sample of corporate press releases from Standard \& Poor's 500 listed large capitalized firms. Yet, investigations of the uptake of CE in industry remain limited hitherto. 
An increasing number of mainly large companies yearly release corporate sustainability (CS) reports which provide their external stakeholders with a description of their sustainability strategies and practices (Montabon et al., 2007; Borga et al., 2009; Siew 2015, Landrum and Ohsowski, 2017). When it comes to companies' approaches to corporate sustainability, CS reports are considered to be their most direct expression (Comas Martí and Seifert, 2013). Hence CS reports have been used as a data source by a growing number of scholars to investigate CS activities. For instance, Comas Martí and Seifert (2013) performed a content analysis of CS reports for a cross-sectoral sample of sustainability leaders to investigate the comprehensiveness of firms' environmental strategies throughout supply chains. Meckenstock et al. (2016) analyzed 142 CS reports across 12 industries to investigate how sustainability evolves from abstract ideas to operational practices across the supply chain. Sihvonen and Partanen (2017) conducted a review of CS reports in the Information and Communication Technology (ICT) sector, to identify, among others, CE-related activities present at companies. However, the overall role and influence of the CE concept in CS agenda were not addressed. The large pool of publicly available CS reports gives the opportunity to explore the role of CE in CS strategies and how companies have been incorporating the core ideas of CE within their main external communication tool.

A sector with large potential in applying CE principles is the Fast-Moving Consumer Goods (FMCG) industry, which includes products characterized by high throughput volumes, frequent purchases and large physical volumes available at relatively low prices (EMF, 2013). FMCG currently account for $35 \%$ of material inputs into the economy, a significant part of total consumer spending on tangible goods, and $75 \%$ of municipal solid waste (EMF, 2012). Within the FMCG sector, food, beverages, textiles, and packaging represent $80 \%$ of the total market by value (EMF, 2013). To our knowledge, no previous study has reviewed the integration and implementation of CE in the FMCG sector. Therefore, this study aims to explore how the recently highly promoted concept of CE affects FMCG companies' sustainability agenda as reported in their CS reports. In this perspective, the study contributes to fill the gap on the missing link between academic research and business practice on CE.

The remainder of the article is structured as follows. In the next section, we provide a theoretical background on CE from which we derive three research questions. Further, the methodology to answer these research questions is introduced. Then, we present the results from the CS reports analysis for each research question and discuss our findings in the light of previous academic work. Finally, we shed light on the limitations of the present study and provide the theoretical and managerial implications of the results, before outlining our conclusions. 


\section{Theoretical background}

\section{The concept of Circular Economy}

The CE concept is not new, yet the momentum recently created around the concept turned into a business approach is without precedent (Sauvé et al., 2016). In their recent analysis of $114 \mathrm{CE}$ definitions both from academic and grey literature, Kirchherr et al. (2017) reveal that a variety of CE conceptualizations coexist. According to Stahel (2016), the objective of CE is "to maximize value at each point in a product's life". The French environment and energy management agency (ADEME) defines the $\mathrm{CE}$ as an economic model which values resource efficiency at every stage of the value chain, stating that "Circular economy aims at reducing the waste of natural resources and more generally aims at protecting the environment (climate change, preserving biodiversity). The transition towards this new economy require the development of new production and consumption models and the involvement of stakeholders at all levels" (ADEME, 2016). It emerged that some authors consider $\mathrm{CE}$ and recycling interchangeably, while practitioners tend to exclude "reduce" from the core principles of CE (Kirchherr et al., 2017). An alignment of the concept among scholars and practitioners is needed, if the CE is to "deliver on its promise of fundamental change" (Kirchherr et al., 2017).

$\mathrm{CE}$ is a concept into which many "Design for X" strategies promoted by the eco-design community (e.g. design for recyclability, design for reuse) and other long-lasting promoted environmental management practices (e.g. material efficiency) can fit in (Moreno et al., 2016). However, a "casual interpretation" of CE can lead practitioners to view it as a mere refreshing of recycling schemes and reverse supply chains rather than a true systemic change (Webster, 2013). CE requires a shift from current systems, rather than an "incremental twist" (Kirchherr et al., 2017). Kirchherr et al. (2017) suggest that the concept of CE is constructed on a set of R-principles (reduce, reuse, recycle, recover), in a systemic perspective, at all economic levels.

The transition towards CE as a new business paradigm is associated with critical challenges in terms of resource management, stakeholder management, financial and regulatory aspects, organizational barriers and consumer acceptance (Stewart et al., 2018; Ritzen and Sandström, 2017). Thus companies' commitments towards CE might remain mainly aspirational (Jones and Comfort, 2017). In this context, there is a risk for business actors to symbolically uptake the concept for greenwashing purposes (Sauvé et al., 2016). CS reports have an important legitimacy role for companies, since through such communication tools they may seek to maintain their license to operate and reduce possible gaps between their stakeholders' expectations in terms of sustainability and their own practices (Hahn and Kühnen, 2013). The risk for organizations to include CE in their CS rhetoric without anchoring CE in their actual practices is thus elevated. Knowledge about how companies understand and conceptualize the CE concept is limited in existing literature. 
133

134

135

136

137

138

139

140

141

142

143

144

145

146

147

148

149

150

151

152

153

154

155

156

157

158

159

160

161

162

163

164

165

166

167

The popularity of CE among both practitioners and scholars has been linked to its promise to attractively operationalize the concept of sustainable development (Kirchherr et al., 2017). Yet, in the definitions they reviewed, Kirchherr et al. (2017) found that in the academic literature CE is mostly linked to the aim of economic prosperity which contradicts some views from industry that CE is strongly related to environmental sustainability (e.g. Lieder and Rashid, 2016). The most circular option is not necessarily the environmentally preferable option when CE is applied on the micro-level (Haupt and Zschokke, 2017). Korhonen et al. (2018) outline that stronger links with environmental science need to be established to guarantee that CE effectively contributes to sustainability. Overall, different ways to position the CE concept in relation with sustainability coexist in literature.

Geissdoerfer et al. (2017) suggest a typology of relationships between CE and sustainability to illustrate the variety of views: a conditional relationship means that $\mathrm{CE}$ is considered as a condition for reaching sustainability; a beneficial relationship means that $\mathrm{CE}$ is considered as one way to progress towards sustainability among others; a trade-off relationship means that CE is considered to lead to sustainability trade-offs (both benefits and negative outcomes). There are academic efforts to conceptually link circular business model and environmental value creation (Manninen et al., 2018). Nevertheless, scholars emphasize the need for methods to assess the environmental, social and economic sustainability performance of circular products and business models (Bocken et al., 2016; Elia et al., 2017; Pauliuk et al., 2018) and a lack of circularity indicators at the micro level (Linder et al., 2017). As far as the industry is concerned, little is known about how companies position CE in their sustainability agenda and measure the sustainability performance of circular approaches.

RQ2: How do companies link CE and sustainability in their CS reports?

\section{Circular Economy practices}

The well-known illustration of CE provided by the EMF distinguishes between the so-called technical and biological metabolisms (EMF, 2013). The technical metabolism illustrates how the value of technical materials should be kept through continuous loops aimed at strategies such as maintain, reuse/redistribute and refurbish/remanufacture, and recycle. The biological metabolism refers to a system where 'nutrients' are designed to re-enter the biosphere safely for decomposition to become valuable feedstock for a new cycle. CE principles can be applied to different application systems, namely packaging, main products or by-products.

According to Bocken et al. (2016), CE is about closing, slowing or narrowing resource loops. Closing loops refers to reuse of material through (postconsumer waste) recycling, slowing loops is about prolonged use and reuse of goods over time, through design of long life goods and product life extension, whereas narrowing loops is about reducing resource use associated with the product and production process, i.e. efficiency improvements (Bocken et al., 2016). Scholars identified three main categories of $\mathrm{CE}$ activities reported by companies, namely resource and waste management (Ghisellini 
et al., 2016; Potting et al., 2016), product design stage (Bocken et al., 2016, Witjes and Lozano, 2016; Linder and Williander, 2017; De los Rios and Charnley, 2017) and development of new business models (Bocken et al., 2016; Lewandowski, 2016). Moreno et al. (2016) proposed a conceptual framework for circular product design by linking available Design for Sustainability approaches to the current literature on circular business models. Beyond design and business model, and as outlined by the CE principles (EMF, 2015), the general optimization of resources and use of renewable resources are also at the core of CE. Thus, sourcing strategies, e.g. the use of recycled content and renewable material, operation strategies, e.g. energy efficiency, use of renewable energy and recovery of operation waste and end-of-life strategies, e.g. actions supporting recycling/recovery infrastructure/initiatives, are also activities under $\mathrm{CE}$. With regard to recycling, the $\mathrm{CE}$ agenda raises the issue of quality of recycling, first introduced in the context of the Cradle to Cradle ${ }^{\circledR}(\mathrm{C} 2 \mathrm{C})$ design framework, through the term "upcycling" which refers to the redesign of ingredients or additives so they improve the quality of materials with respect to maintaining or improving value in continuous loops (McDonough and Braungart, 2002). Korhonen et al. (2018) argue that one specific contribution of CE is its focus on the importance of high value and high quality in material cycles.

Another key area of CE practice is collaboration in business ecosystems which is outlined as one pillar of a transition towards a well-functioning CE (Witjes and Lozano; 2016). Collaboration is also closely related to the system perspective which is another fundamental aspect of CE practice (Webster, 2013). There has been limited attempts to explore CE practice in the industry (De los Rios and Charnely, 2017; Jones and Comfort, 2017), and broader investigations are recommended by scholars (Moreno et al., 2016).

RQ3: Which CE practices do companies present in their CS reports?

\section{Methodology}

\section{Sample definition}

The sample of companies to be included in this study was systematically built using the Corporate Register database. It is the largest online database of CS reports with possibility of doing content searches (CR, 2017), previously used by Bjørn et al. (2016) in a similar context, i.e. to perform a comprehensive review of references made to ecological limits in CS reports in 2000-2014. Corporate Register seeks to include all sustainability reports "without limitations of country or company size and across all sectors, public and private" and it estimates that more than $90 \%$ of all reporting companies and other organizations are covered in the database which is updated daily (CR, 2017). The database includes any type of sustainability reports in Latin-script, e.g. integrated report, sustainability and environmental reports (CR, 2017). In January 2017, we identified all sustainability reports of companies (i.e. excluding other organizations) listed in the above-mentioned database released until 
2016 and mentioning at least once the term "circular economy". The term "circular economy" was specifically searched for, rather than including other entries connected to the topic such as "closedloop" and "close the loop". Indeed, the focus of this study is to explore the influence of the recently highly promoted concept of CE on corporate sustainability strategies. We do not aim to explore the extent to which CE-related practices are already used in the industry at large, e.g. reuse and recycling of production waste or use of recycled material, but we focus on how companies uptake the CE concept as a source of inspiration or even a new framework for their sustainability work.

The temporal evolution of the resulting CS reports is illustrated in Figure 1, showing that the popularity of the CE term drastically increased in 2015 and 2016. Such increase could be correlated with the release of the first EMF report in 2012 (EMF, 2012) and the first European Communication on CE (EC, 2014). A total of $630 \mathrm{CS}$ reports were retrieved, among which we selected those published in 2016 (representing more than half of all CS reports mentioning "circular economy") by companies in the FMCG sector, i.e. Food \& Beverage, Household Goods \& Textiles, Packaging, and Personal Care \& Household Products. Additionally, we included the CS reports of the FMCG companies listed in the CE100 directory and founders of the EMF (EMF, 2017a), provided that they contained information about $\mathrm{CE}$, since these companies are expected to be engaged with $\mathrm{CE}$.

The final sample contains 46 CS reports released by 46 companies (See Table A1) whose geographical and sectoral distributions are shown in Figure A1. Most companies included in the sample belong to the Household Goods \& Textiles (39\% of the sample) and Food \& Beverage (37\%) sectors, meanwhile a limited set represents the Personal Care \& Household Products (11\%) and Packaging (13\%) sectors. In terms of geographical distribution, the majority of the companies included in the analysis are based in Europe (i.e. $65 \%$ of the sample) and North America (26\%). Companies from Africa, Asia and Oceania are represented to a very limited extent, i.e. $2 \%, 4 \%$ and $2 \%$ of the sample, respectively. This differentiated distribution may be partially explained by the relative representation of sectors and regions in the Corporate Register database, i.e. the database contains fewer reports in the Packaging sector than in the Household Goods \& Textiles sector and European reports represent almost half of all reports while South America and Africa only a few percentages. Considering the explorative nature of the present study, no statistical tests were used to search for differences between sectors and regions. Nevertheless, similarly to the study by Comas-Martí and Seifert (2013) also performed on a rather limited set of CS reports, the main differences found in our results are qualitatively indicated in the results when relevant, between North America and Europe, and between Food \& Beverage \& Household Goods \& Textiles which concentrate most of the sample.

\section{Analysis methodology}

In order to answer the research questions previously formulated, we systematically analyzed the content of the CS reports using (i) a content analysis approach (RQ1 and RQ2) and (ii) a mapping approach (RQ3). The stepwise procedure adopted for the analysis is displayed in Figure 2. 
240 RQ1 and RQ2 are both directly related to how companies present the CE concept in their CS reports. 241 Thus, an analysis of meaning (or recording) units where CS reports introduce and discuss CE seemed 242 best suited to address these questions. Meaning units are defined as sets of sentences "containing 243 aspects related to each other through their content and context" (Graneheim and Lundman, 2004). As 244 first step, all extracts where companies make explicit reference to CE were systematically collected 245 from reports and stored as recording units in an excel sheet, similarly to the approach adopted by 246 Hrasky (2011) to study the topic of "carbon footprint" in CS reports. We identified as explicit reference to CE where the company makes reference to "circular economy", but also more broadly to "circular", e.g. "circular model”, "circular business", "circular development", "circularity", "circular thinking", to account for slightly different terminology. The second step consisted in coding the recording units, using a combined deductive and inductive approach (Hsieh and Shannon, 2005), as shown in Figure 2.

251

252

253

254

255

256

257

258

259

260

261

262

263

264

265

266

267

268

269

270

271

272
For RQ1 we first coded the recording units against the list of " $R$ " principles adapted from the work by Kirchherr et al. (2017). The coding of "R" principles was assisted with keyword searches taken from Kirchherr et al. (2017) and complemented with keywords inductively derived from the data (see the list of keywords used in Table A2). Occurrences were checked for relevance with the principles of CE, e.g. in the case of a reference to "reduce" as "reduction of greenhouse gases", the occurrence was ignored. Second, we coded the recording units for references to the systemic dimension of CE (see Table A3). Third, we coded the recording units against the categories "general statement", i.e. general statements or aspirations about CE, versus "concrete activities", i.e. concrete activities undertaken by companies in relation with CE (see Table A3).

For RQ2, we first coded meaning units against sustainability aspects they mention (environmental, economic, and social). Second, we used a deductive approach based on the first-level typology of relationships between sustainability and CE suggested (conditional, beneficial and trade-off) by Geissdoerfer et al. (2017), see Table A3. If distinct relationships could be retrieved from different meaning units in the same report, an unclear relationship was indicated. Last, we inductively noted for each CS report if sustainability performance indicators or assessment methodologies were indicated in relation to the $\mathrm{CE}$ approach at the company.

\section{Mapping}

In order to answer RQ3, we adopted a mapping approach, similarly to Roca and Searcy (2012) and Kozlowski et al. (2015) in their investigation of sustainability indicators in CS reports. Contrarily to RQ1 and RQ2, which address explicit references of CE in CS reports, RQ3 focuses on CE practices whether they are labeled under CE by companies or not. Thus, full reports had to be considered and a mapping approach was deemed better suited than the coding of full CS reports. 
With regard to the activities, we adapted the framework developed by Moreno et al. (2016), including circular design strategies, i.e. design for closing resource loops, design for reducing resource consumption, design for reliability $\&$ durability, design for product attachment $\&$ trust, design for extending product life, design for dematerialization of products, design for resource recovery, design to reduce environmental backpacks (terms used by the authors to refer to design for the entire value chain and for local value chains) and design for regenerative systems and circular business model archetypes (circular supplies, resource value, product life extension, extending product value, and sharing platform), by adding sourcing, operations and end-of-life activities. The full mapping framework of CE activities is displayed in Table A4. With regard to the application systems, we distinguished between "main product", "packaging" and "by-products", further classified into technical and biological systems. For collaboration practices, inductive categories were formed based on collaboration aspects mentioned both in the meaning units collected in the content analysis and in relation with CE activities. The inductive categories are: research/innovation/technology development project; support of local recycling system; working group/forum/dialogue; system for circulating goods; partnership for reprocessing; and campaign/education.

Validity and reliability are two important criteria to be addressed in any research design and were enhanced through researcher triangulation throughout the study. Each researcher reviewed half the sample of CS reports. The analysis for each research question was first performed by a single author and second checked for consistency with the second author. Both authors discussed each critical case until consensus could be obtained (Bengtsson, 2016). On the other hand, an important aspect to increase reliability is to ensure a clear-cut definition of coding categories: basing categories on concepts established in literature for most RQ facilitated differentiation between categories (Kohlbacher, 2005).

\section{Results and discussion}

\section{How is companies' uptake of Circular Economy in their corporate sustainability reports?}

In most CS reports, no clear-cut definition for $\mathrm{CE}$ is provided by companies, yet defining elements can be retrieved in extracts where $\mathrm{CE}$ is introduced by most companies. Several companies make reference to the EMF (Amcor, Luigi Lavazza, Tetra Pak, H\&M, CCE, Sealed Air Corp, Groupe SEB, IKEA, Tarkett) and the EU Action plan (Karl Fazer, Heineken, CCE, SCA, IKEA) when mentioning CE. Figure 3 shows the respective presence of the "R" principles in extracts where CE is referred to in CS reports. "Recycle" is mentioned in almost two third of reports, and to a lesser extent, "reuse" (40\%), reduce (35\%) and "recover" (20\%) also appear in CE extracts. The Food \& Beverage sector contains more reference to "recover", and less to "recycle" which can be related to the importance of byproducts recovery in this sector (see Table A7).

Around one third of the sample (17 CS reports) contains references to a systemic change related to CE (see Table A5). These CS reports mention e.g. the will to "lead the fashion industry away from the 
make, use, dispose economy to one that allows us to keep resources in use for as long as possible" (C\&A, 2016), the idea that "resources and products should be designed and used in continuous loops" (Carlsberg, 2016) or reference to a "future society based on a circular economy" (Åhlens, 2016).

One fourth of the sample (11 CS reports) contains only extracts referring to CE coded as "general statement" as shown on Figure 3. For instance, Åhlens (2016) simply mentions its ongoing reflection about the role that the company can play "in a future society based on a circular economy"; MayrMelnhof Karton (2016) states that "circular economy is thus an immanent part of our business activity" and Ball (2016) argues that its "[metal] cans represent a perfect example of truly recyclable packaging and a product that fits a circular economy model very well". All other CS reports contain at least one extract where $\mathrm{CE}$ is mentioned in relation with concrete activities, e.g. joining the New Plastics Economy initiative "for a more effective plastics system based on circular economy principles - a new plastics economy" (Amcor, 2016), creating a hub to incubate circular technologies (C\&A, 2016), launching a rental service system of kitchen appliance (Groupe SEB, 2016) or valorizing operations' by-products (Pernod Ricard, 2016).

All in all, our findings show that in reviewed CS reports, CE is mostly associated with the idea of recycling and reusing, its systemic dimension is referred to in one-third of the sample and in most CS reports it is associated to concrete activities, as opposed to sole general statements. With regard to the presence of " $\mathrm{R}$ " principles in CE definitions, our results are aligned with the findings of Kirchherr et al. (2017). The lesser presence of "reduce" (in comparison with "recycle" and "reuse") in our results echoes their findings for practitioner definitions in comparison with academic definitions, which they argue can be explained by the negative connotation of this principle for economic growth. Furthermore, Kirchherr et al. (2017) found that definitions of CE rarely contain a reference to the systemic dimension of CE, which seems to hold true as well in our sample of CS reports. Our results show that overall the discussion about CE in CS reports is articulated around concrete activities and does not remain solely on an aspirational level, although symbolic references to CE in CS reports could have been expected considering the strong traction of CE in the industry (Jones and Comfort, 2017).

\section{How do companies link Circular Economy and sustainability in their CS reports?}

Different aspects of sustainability, i.e. environmental, economic and social aspects, are mentioned in CS reports in relation with CE as show in Figure 4. The most mentioned aspects are environmental ones (around 50\%), either in relation with resource scarcity, climate change or more generally environmental pressures, followed by economic aspects (around 30\%). Social aspects are largely ignored in references to $\mathrm{CE}$ in $\mathrm{CS}$ reports.

The analysis on the linkage between CE and sustainability reported in Figure 4 suggests that for around $75 \%$ of CS reports there is an unclear linkage, and CE seems to be considered as a purpose to be pursued per se in many CS reports. What is most interesting to note is that no company outlines the existence of trade-offs between $\mathrm{CE}$ and sustainability, therefore suggesting that $\mathrm{CE}$ inherently 
contributes to the sustainability agenda. On the other hand, companies might be aware of trade-offs, but decide not to expand on them in CS reports, which are targeted to a non-technical audience. A few examples of beneficial (Barilla, Growmark, Inditex, Luigi Lavazza, Tarkett) and conditional (Carlsberg, CCE, Colgate, Davines, H\&M, IKEA) relationships could be inferred from companies' narratives about CE in 2016 (See Table A6 for the details of coding results). For instance, IKEA (2016) states its aim to "converting to a circular economy" in order to address the Sustainable Development Goal 12, "ensure sustainable consumption and production patterns", which expresses a conditional relationship. Luigi Lavazza (2016) is "developing sustainable solutions that are inspired by the philosophy of a circular economy", thus outlining a beneficial relationship.

References to sustainability performance indicators or assessment methodologies were lacking in most CS reports which elaborate on CE. Only a minority of companies presents a dedicated set of Key Performance Indicators (KPIs) for their CE approach. CCE (2016) uses a set of KPIs to achieve their goal to "support the development of the circular economy, use recycled and renewable materials and recycle more packaging than [they] use" and which includes among others percentage of recycled material used, percentage of renewable material used, percentage of weight reduction, percentage of recyclable products and amount of items collected or recycled. Fromageries Bel (2016) reports on its recovered byproducts in the section "circular economy". We also found that Carlsberg's and SCA's 2016 CS reports, mention their use of the life cycle assessment (LCA) methodology in parts where CE is discussed. Similarly, CCE (2016) explicitly mentions reducing its carbon footprint in relation with CE. On the other hand, most companies do mention footprint methodologies (LCA, carbon footprint or water footprint) elsewhere in their reports, with no link with CE. Furthermore, we found three companies mentioning the $\mathrm{C} 2 \mathrm{C}$ design framework and $\mathrm{C} 2 \mathrm{C}$ certification program as a performance indicator (Carlsberg, 2016, Tarkett, 2016, and Shaw Industries Group, 2016).

Interestingly, our results show that environmental challenges are present in companies' narratives about CE, which contrasts the findings of Kirchherr et al. (2017) who found economic prosperity to be the mostly mentioned aim in CE definitions. On the other hand, our findings confirm that the social aspects are barely mentioned in relation with CE (Kirchherr et al., 2017). Most examples found in academic literature describing the link between $\mathrm{CE}$ and sustainability refer to a beneficial relationship, meanwhile only a limited set of authors refer to the possibility of trade-offs (Geissdoerfer et al, 2017). This is consistent with the absence of tradeoffs relationship in our analysis. In addition, the high presence of unclear linkage suggests that companies regard $\mathrm{CE}$ as inherently contributing to the sustainability agenda. Our results further show that most companies do not link CE with sustainability assessment which stress the need for performance indicators and assessment methodologies outlined in academic literature (Linder et al., 2017; Pauliuk, 2018). The references to LCA and other footprint methodologies in companies' CS reports show potential for them to explore the environmental sustainability relevance of CE-related activities. LCA has been explored in several studies as a tool to evaluate the environmental sustainability potential of CE approaches (Niero et al., 2016; Haupt and Zschokke, 2017; Niero et al., 2017) and is outlined as a promising tool (Elia et al., 2017), meanwhile 
the $\mathrm{C} 2 \mathrm{C}$ certification program should be used with caution as a way to monitor environmental performance (Niero et al., 2016).

\section{Which Circular Economy practices do companies present in their CS reports? Which systems do companies apply Circular Economy activities to?}

As illustrated in Figure 5a, most of CE-related activities are oriented towards the main product and packaging. Particularly in the Food \& Beverage sector, efforts are aiming at implementing CE strategies to packaging (see Table A7). This trend is confirmed by analyzing the type of nutrient cycle which CE-related activities are applied to. As shown on Figure 5b, almost all companies refer to CErelated activities with regard to the technical cycle and around one-third of the sample report actions in both cycles.

Our findings can be explained by the prominent role that has been given to packaging both in the business agenda, particularly plastic packaging e.g. in the EMF reports (EMF, 2017b, 2013) and in the political agenda, e.g. the recycling targets for packaging waste included in the EU Action Plan for CE (EC, 2015). Both plastic and food waste are included as focus areas in the EU Action Plan for CE (EC, 2015), but from our analysis little emphasis has emerged on food waste reduction in the Food \& Beverage sector.

\section{Which Circular Economy activities do companies apply?}

As illustrated in Figure 6, among CE-related activities, most companies report initiatives addressing improvement in their operations, such as energy efficiency, increased share of renewable energy and recovery of production waste. The second most spread activities in the ranking are connected with raw material sourcing and with promoting the use of recycled content or renewable material. Almost half of the companies report engagement in supporting recycling and resource recovery infrastructure through recycling campaign or initiatives with suppliers.

Our findings show that activities addressing circular product design and circular business models are reported to a lesser extent, except for design for reduce resource consumption and design for resource recovery. Within the former category, most of the reported activities aim at design for light weighting, e.g. Barilla (2016), Bonduelle (2016), and Diageo (2016), and design for reducing material/resource use (e.g. Marimekko, 2016, Mohawk Industries, 2016 and P\&G, 2016). In terms of design for resource recovery, the emphasis is on the recyclability of the products or packaging, e.g. SCA (2016), Groupe SEB (2016) and Nike (2016). The Household Goods \& Textiles sector is the only one with examples in extending product life both in the design stage (mainly through design for easy maintenance, reuse, repair) and circular business models, by primarily setting take back systems for reuse, e.g. H\&M (2016), KappAhl (2016), for repair (e.g. IKEA, 2016) and to a lesser extent by extending product value through rental service (e.g. Tarkett, 2016) (see also Table A7). 
417 Most activities reported by companies with regard to recycling focus on the quantitative aspect of 418 recycling. Some reports tackle the importance of maintaining the quality of material, therefore highlighting a more advanced analysis of the CE challenges (Carlsberg Breweries, 2016, H\&M, 2016, Inditex, 2016). Some companies even recognize the challenges inherent in keeping material quality. Pespsico (2016) highlights the need to "eliminating materials in Pepsico designed packaging that impact recycling sorting or contaminate recovery stream" in order to achieve their 2025 goal of designing $100 \%$ of their packaging "to be recoverable or recyclable". Nike (2016) sees "chemistry as an important tool to unlock some of the key innovations for the future, including performancemaximizing material, component improvements and overcoming roadblocks to closed-loop processing".

Based on Bocken et al.'s (2016) categorization it can overall be concluded that the reviewed companies primarily report the implementation of activities aiming at narrowing loops, somehow already in place in linear economic system, secondly closing loops and only to a limited extent slowing loops. No examples were found for design for dematerialization of products and design for trust \& attachment, which are circular design strategies more strongly connected to consumer behaviors. Circular business model strategies are also very limited in the sample. Although the activities considered in this mapping were included whether labeled under the CE or not by the company, the results reveal that among the activities at the core of a $\mathrm{CE}$, the reviewed companies seem to be very involved in resource-efficiency measures in their operations and sourcing, but less active when it comes to circular offers through design or business model initiatives. These outcomes confirm the findings of Kirchherr et al (2017), i.e. that circular business models are mentioned only marginally within CE conceptualizations. Blomsma and Brennan (2017) outline that the value of CE in the broader debate around resource and waste is to put forth a set of "strategies to extend resource life as a means to facilitate additional value extraction and reduce value loss and destruction". Yet our results indicate that only a limited set of the latter strategies seem to be implemented by the reviewed companies. Interestingly, this lack of a larger set of circular strategies in current activities is coupled with limited references to maintaining material quality, although it is one main strength of the CE concept in comparison with other sustainability initiatives (Korhonen et al., 2018; Webster, 2013).

\section{Which CE-related collaboration practices do companies have?}

446

447

448

449

450

451

452

453

More than half of CS reports indicate collaboration(s) with external players in a CE-related context. As shown in Figure 7, the most common collaboration types are working group/forum/dialogue identified in nearly a third of CS reports and research/innovation/technology development project identified in nearly a fourth of CS reports. Working group/forum/dialogue collaborations reveal that several companies have initiated or engaged in active dialogue with e.g. peers, knowledge partners, value chain partners and regulators, to explore the role of CE in their specific business. For instance, Carlsberg (2016) has established the Carlsberg Circular Community as a forum for the beverage value chain to explore future circular packaging options. IKEA (2016) is part of a coalition of companies with 
Michelin, Phillips, Unilever, DSM, Suez, Tetra Pak and Umicore to advocate changes to the EU CE Package.

Research/innovation/technology development project collaborations reveal that concrete projects are already happening in several companies to implement CE principles concretely in their technologies and products together with relevant players such as innovation consultancy, knowledge partners, competitors, technology developer. For instance, H\&M (2016) in partnership with Kering and Worn Again works on developing a textile-to-textile recycling technology. Amcor (2016) participates in the Project Reflex, which is a "UK-based program evaluating the recyclability of films and multilayer laminates through innovative product designs and recycling technologies", meanwhile C\&A's Foundation hosts a technology innovation incubator to boost CE initiatives (C\&A, 2016). These collaborations mainly focus on technological innovation and to a lesser extent on consumer-based research and design. One notable exception is CCE's (2016) research on recycling behavior of 20 households in Great Britain and France together with the University of Exeter.

Partnership for reprocessing and system to circulate goods can be directly related to the respective circular business model strategies resource value and product life extension. They respectively involve joint ventures with recycling factories or cooperation with secondary raw material suppliers on the one hand; and on the other hand collaboration with online platforms, retailers, charities or reprocessors. For instance, Shaw Industries Group (2016) has a joint venture with the company DAK Americas which is a manufacturer of monomers, resins and fibers, to run a recycling facility (resource value) and $\mathrm{H} \& \mathrm{M}$ (2016) collaborates with the online platform Sellpy to support sales of items that are not used anymore by consumers (product life extension). For such circular business model strategies to thrive, more collaboration with external players will be needed in the future.

Our results reveal that part of the companies already engage at different levels with their business ecosystem in relation with the $\mathrm{CE}$, which goes in the direction of academics outlining the importance of business ecosystem interactions for a transition towards the CE (Witjes and Lozano, 2016, Linder and Williander, 2017). Yet, interestingly most identified collaborations are with businesses, and few initiatives focus on consumers apart from some campaigns and education initiatives. This seems to confirm trends outlined in literature (Young et al., 2017, Kirchherr et al. 2017; Jones and Comfort, 2017; Hazen et al., 2017) that consumer involvement and acceptance are largely missing although considered critical for a transition towards the CE.

\section{Limitations, implications and future research}

\section{Limitations of the study}

Our study presents some limitations which should be highlighted before deriving theoretical and managerial implications. First, the data set only contains FMCG companies that publish CS reports in English. This implies that the sample excludes most small and medium companies which often do not 
publish such reports (Borga et al., 2009) and is under-representative of countries where it is not common to publish CS reports or to communicate in English. For example, Chinese companies are reported to implement $\mathrm{CE}$ in literature, but their experience and views were very limitedly addressed in the present study since only one Chinese company was identified as fulfilling the sample criteria. The sample also excludes companies that use the CE concept, but did not communicate about it in their 2016 CS reports. For instance, Unilever has a full section dedicated to CE on its website (Unilever, 2017), but does not address the topic in its CS report published in 2016 (Unilever, 2016). In this perspective, the sample included in this study cannot be considered fully representative of the FMCG sector at large. Future work is needed to appraise CE uptake in the sector more comprehensively and to statistically account for differences across sub-sectors and regions, which was outside the scope of this study. Moreover, the role of institutional factors, e.g. laws, norms or beliefs in specific regional contexts, on CE uptake in the industry could be particularly interesting to explore (Ranta et al., 2017).

Furthermore, the source of information used to analyze each company is limited to its CS report published in 2016. The latter only gives selected insights of the company's sustainability work, since it outlines key topics of that year, filtered by the company's communication team and according to stakeholders' concerns. The time scope in this study did not allow any longitudinal exploration of companies' activities that is, through comparing reports across years (Hrasky, 2011). Thus it was not possible to investigate further a possible symbolic uptake of CE in CS reports. Moreover, CS reports are concise documents presenting practices that may have reached a certain maturity in the organization, thus the information communicated in CS reports might be too thin to appreciate actual ongoing efforts towards CE. Results based on CS reports provide a partial picture and must be taken with caution when drawing conclusions at the level of the companies that publish these reports. Hence, future work based on longitudinal and primary data is needed. Yet, we consider that what companies provide about $\mathrm{CE}$ in their CS reports delivers relevant information about business thinking around the concept and allows for providing insights and trends about the business uptake of CE.

\section{Theoretical implications}

Our study contributes to the academic knowledge of CE uptake at a micro-level and sheds light on several aspects particularly relevant for the CE research community. First, only limited symbolic references to CE could be elicited, whereas most of the CS reports considered report concrete actions on CE implementation. Second, the systemic dimension of CE is not systematically acknowledged in CS reports and rather poorly represented in practices, i.e. limited focus on business model changes, consumer engagement and material quality. The "reduce" principle is under-represented in companies' narratives about $\mathrm{CE}$. These findings are consistent with previous observations in the academic literature (Kirchherr et al., 2017) and indicate the need for research to further inspire and support business players towards systemic changes and more radical innovations in their businesses if the $\mathrm{CE}$ is to deliver on its promises (Kirchherr et al., 2017). Although we found that most companies envision CE as a way of addressing their environmental challenges, their understanding of the linkage between 
sustainability and CE remains implicit or absent and CE-related practices are rarely associated to sustainability assessments or performance indicators. These results show that $\mathrm{CE}$ remains primarily regarded by companies as a vision (Goedkoop et al., 2015) and strengthen the existing call in academia for more methods which allow evaluating how good a CE strategy is from a sustainability perspective, i.e. including environmental, economic and social aspects (Niero and Hauschild, 2017). If not assessed, the relevance of $\mathrm{CE}$ approaches could be challenged due to overlooked burden shifting. Based on these considerations, we strongly recommend an increased focus on the systemic dimension and sustainability relevance of CE in future academic work on the implementation of CE in business sustainability strategies.

\section{Managerial implications}

Although our study reveals that the CE concept has started being implemented in corporate sustainability agendas of the reviewed FMCG companies, our findings highlight that its concrete application can be strengthened in different ways. We encourage practitioners to reflect on the meaning of $\mathrm{CE}$ for their business activities, beyond sourcing, operations efficiency and end-of-life initiatives, e.g. by taking a multiple life cycle perspective, i.e. considering material quality and limitations to recycling (Grosso et al., 2017) and rethinking their product design and business models, in collaboration with consumers and other business partners. If CE is "casually interpreted" (Webster, 2013) and its application remains constrained to narrowing loops (Bocken et al., 2016) while failing to challenge our production and consumption models more broadly (ADEME, 2016), there is a risk to miss out opportunities to drastically reduce pressures on earth's resources. Our results further reveal that CS reports seem to convey a strong faith in the CE as an approach to solve environmental challenges in the industry, which is consistent with its key role as a clear vision to move away from the throw-way society. However, practitioners are encouraged to clarify their objectives to engage in $\mathrm{CE}$ activities and perform quantitative sustainability assessment or hotspot analysis to avoid burden shifting between life cycle stages.

\section{Conclusions}

This explorative study aimed to contribute to fill the gap on the missing link between academic research and business practice on CE by investigating how the CE concept affects FMCG companies' sustainability agenda as reported in their CS reports. The 2016 CS reports of the 46 companies in the FMCG sector identified as referring to "circular economy" were systematically analyzed to unearth (i) their uptake of the CE concept, (ii) the linkage established between CE and sustainability and (iii) the breadth of CE-related practices undertaken by these companies. A fair share of CS reports indicate concrete activities in relation to the concept of CE, mainly oriented towards the main product and packaging, which reveals that companies have started a journey towards CE implementation. However, our analysis revealed that the breadth of CE-related activities remains to be explored and the systemic dimension of CE is rarely present in companies' narratives about $\mathrm{CE}$, as well as poorly rooted in $\mathrm{CE}$ - 
562 related activities (i.e. limited focus on consumer engagement, material quality, and business models).

563 Furthermore, the results show that the linkage between CE and sustainability remains largely implicit

564 both conceptually and practically due to limited use of performance indicators or quantitative

565 sustainability assessments. Based on these findings, we outlined the need for researchers and

566 practitioners to respectively further explore and support the systemic dimension of CE and its link with

567 quantification of sustainability performance. Our findings are a first attempt to systematically explore

568 CE conceptualization and related practices in a business context for FMCG, but cannot be generalized

569 to the whole sector, and neither can give a direct account for the actual practices of the reviewed

570 companies. Future work should thus expand our analysis by exploring other periods of time and sectors

571 to test the statistical significance of differences among sub-sectors and regions, as well as focusing on

572 in-depth investigations of companies' approaches to CE based on interviews and field studies.

\section{$573 \quad$ Acknowledgements}

574 Monia Niero deeply acknowledges the Carlsberg Foundation for funding the project "Absolute Circular

575 Economy" (ACE) toolkit to support companies in the implementation of Circular Economy strategies

576 from an Absolute environmental sustainability perspective". The authors acknowledge Peter Fantke for

577 his help in processing the list of corporate sustainability reports, as well as the three anonymous

578 reviewers for their constructive suggestions on how to improve the paper.

579

580

581

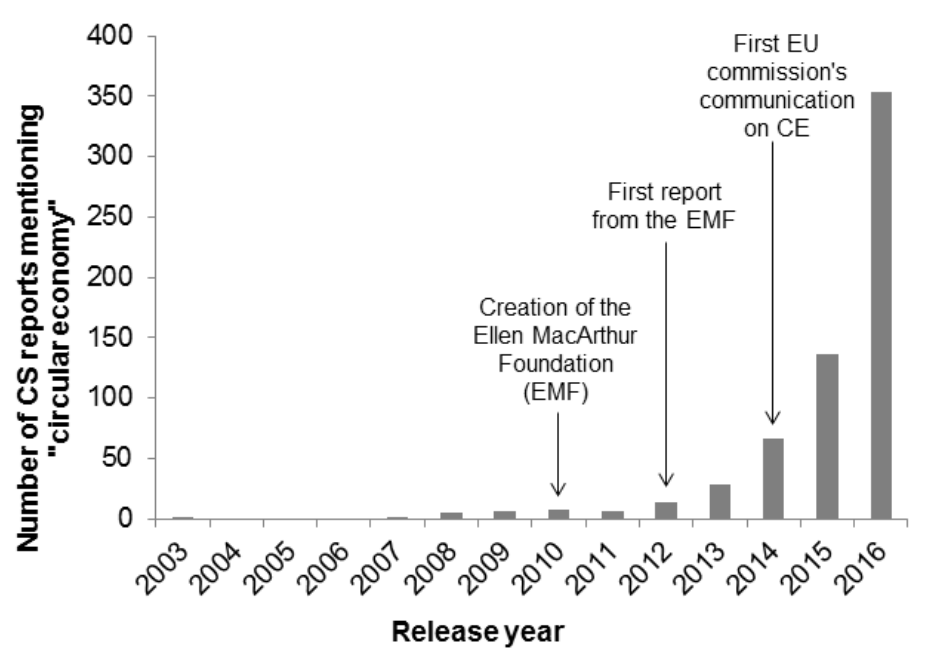

Figure 1. Temporal evolution of corporate sustainability (CS) reports included in the Corporate Register database mentioning the term "circular economy" (CE). EMF: Ellen MacArthur Foundation. 


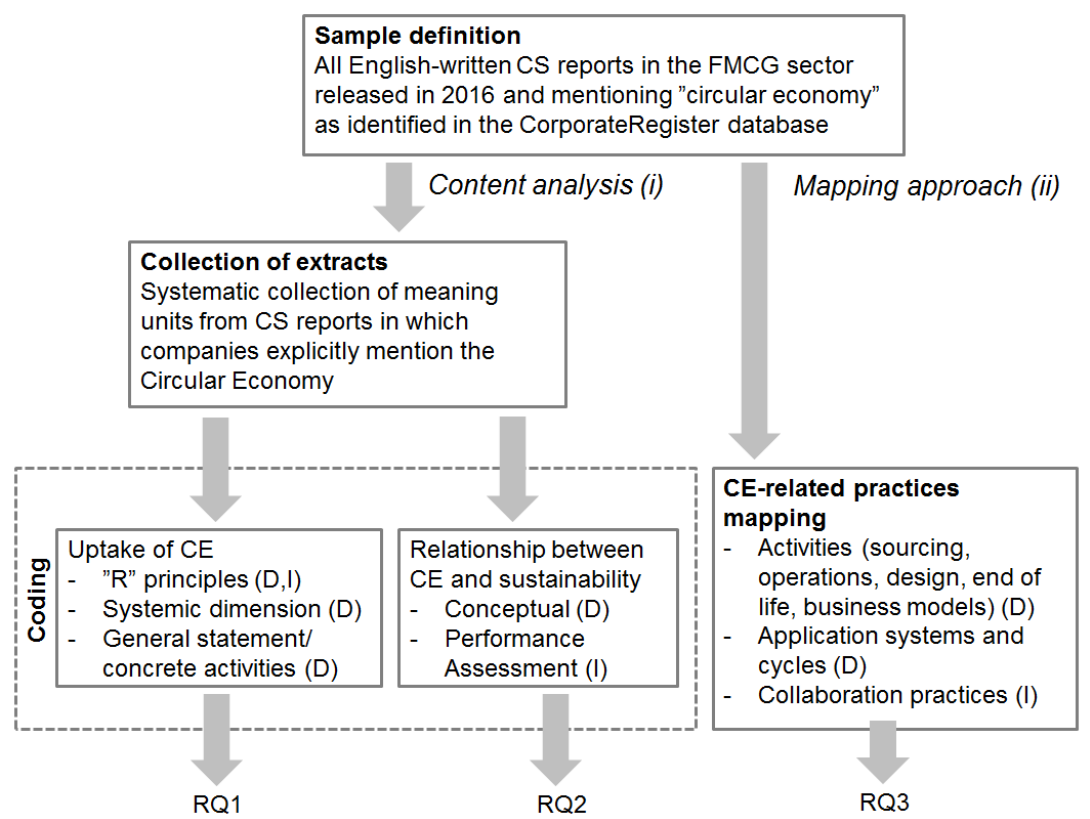

584 Figure 2. Stepwise procedure used to answer the three research questions (RQ), with indication of the 585 methodological approach adopted. $\mathrm{CE}=$ Circular Economy, CS= Corporate Sustainability, FMCG = 586 Fast Moving Consumer Goods. I= inductive approach. D= deductive approach.

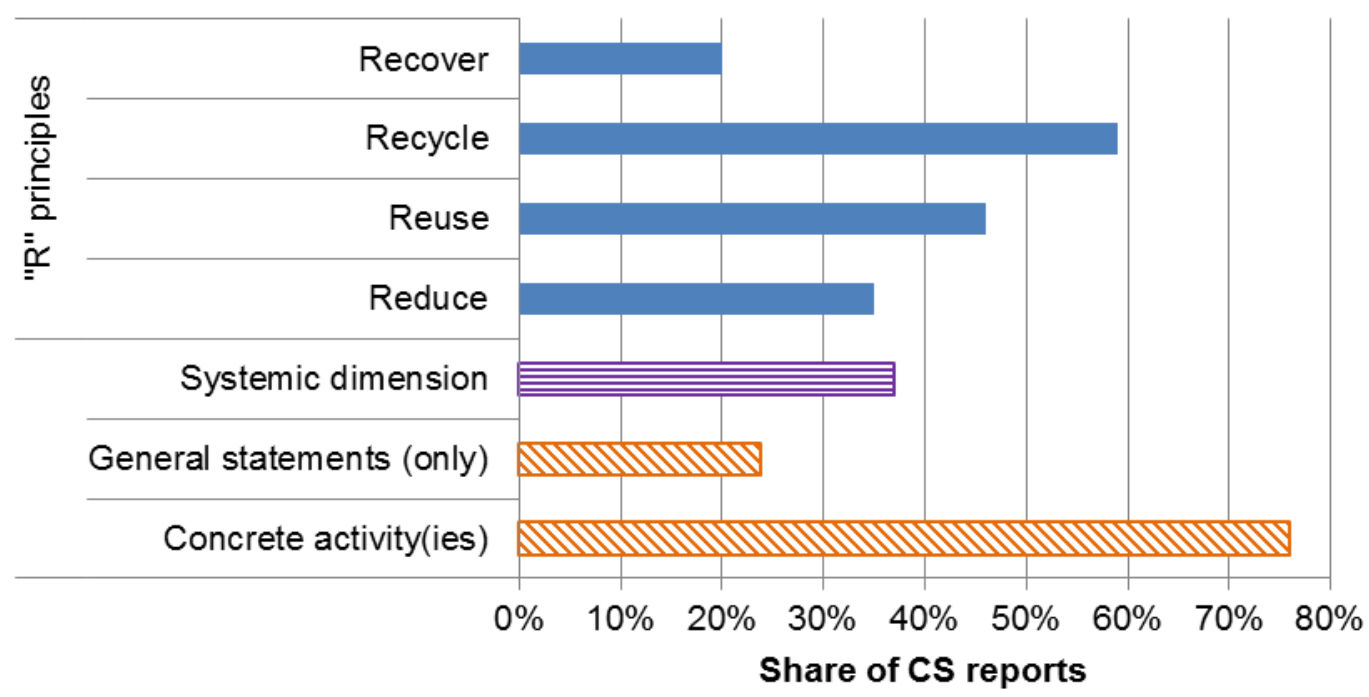

587

588 Figure 3. Main conceptual elements used by companies to introduce and/or define Circular Economy 589 in their corporate sustainability (CS) reports, with regard to the "R" principles introduced by Kirchherr 590 et al. (2017), link to systemic dimension and presence of either general statement (only) or concrete 591 activities in relation to CE. 


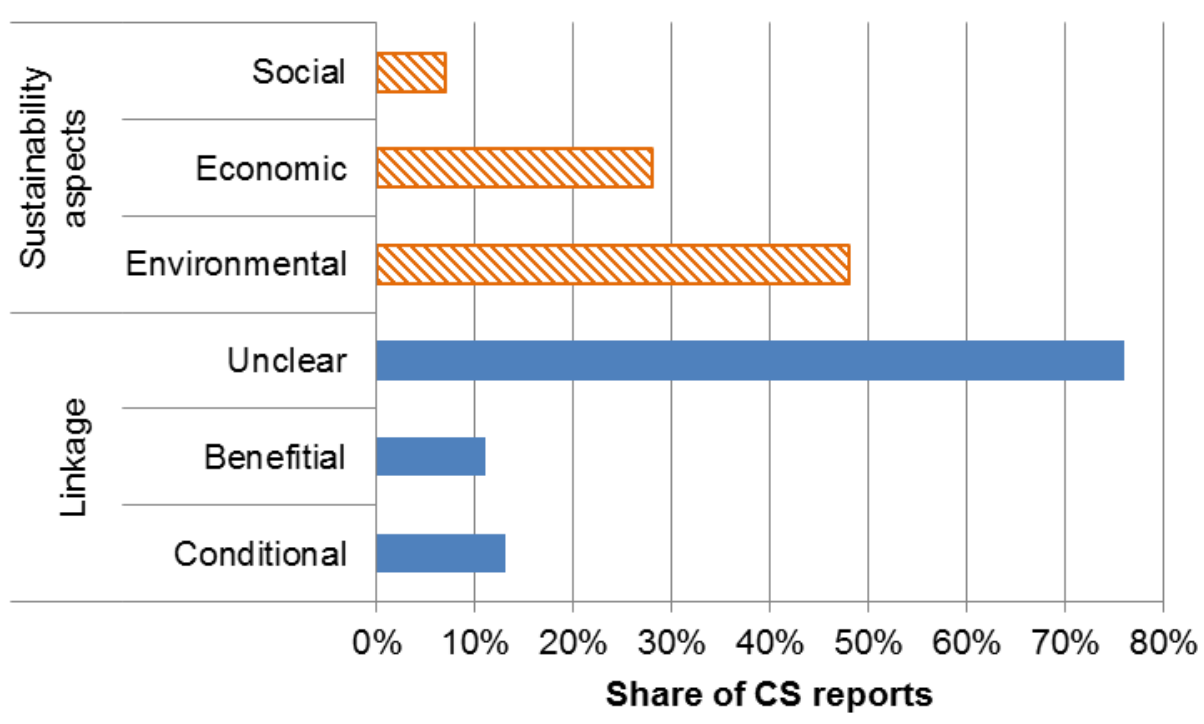

594 Figure 4. Share of corporate sustainability (CS) reports for (i) sustainability aspects associated to 595 Circular Economy (CE) and (ii) different linkages between CE and sustainability based on the 596 categories introduced by Geissdoerfer et al. (2017).

597
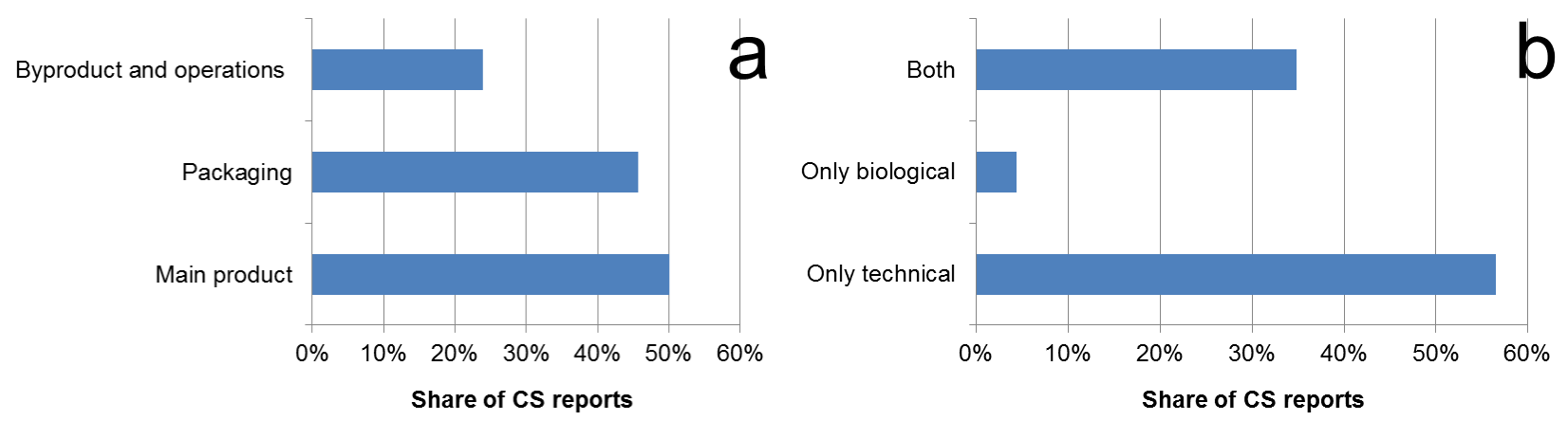

599 Figure 5. Systems where Circular Economy-related activities are applied to (a) and nutrient cycles 600 considered (b). Note that the percentages do not sum up to $100 \%$ in Fig. 5 b because no system could be 601 identified in 2 corporate sustainability (CS) reports.

602 


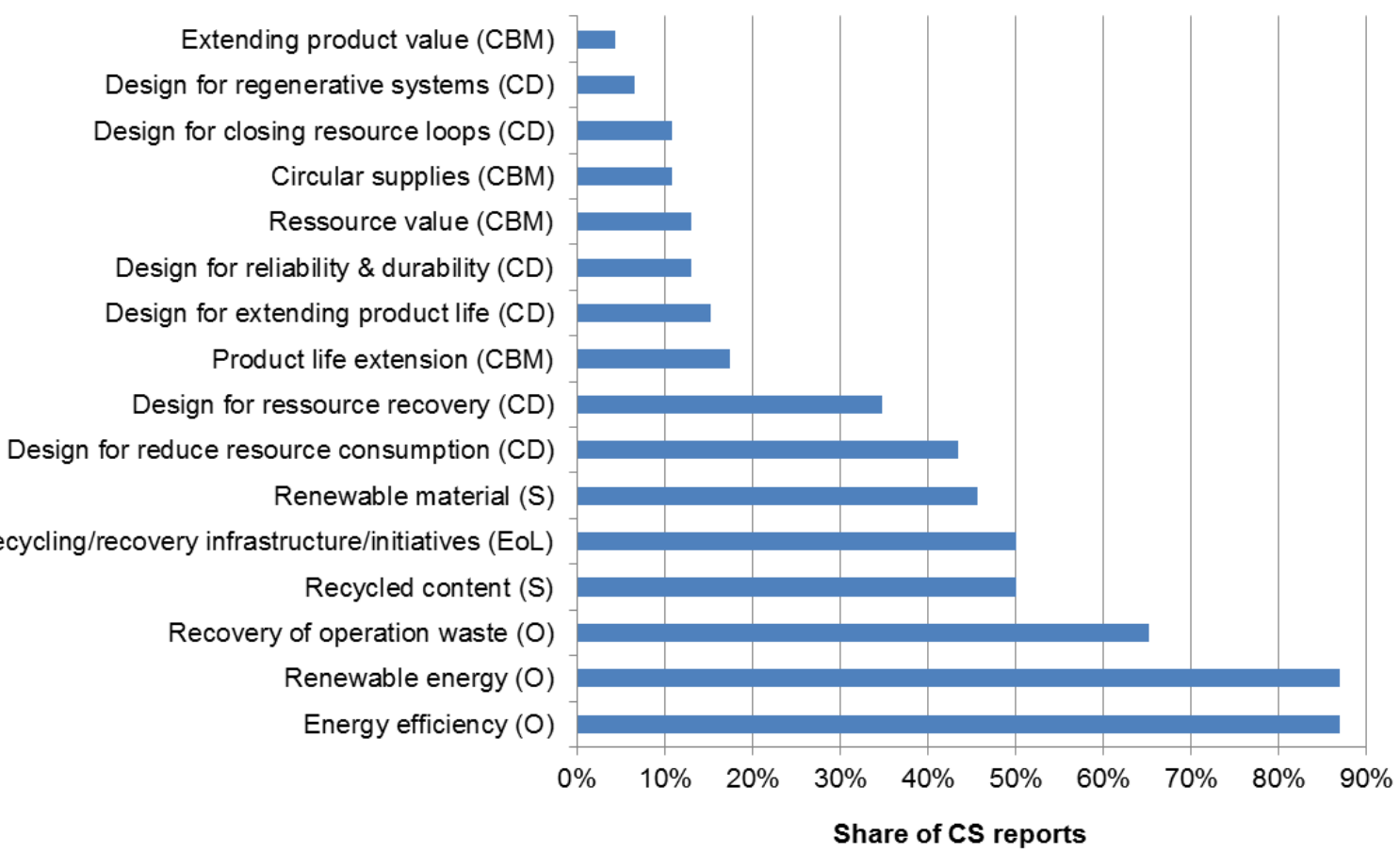

603 Supporting recycling/recovery infrastructure/initiatives (EoL)

Recycled content (S)

Energy efficiency $(O)$

Share of CS reports

604 Figure 6. Summary of Circular Economy-related activities reported by companies in their corporate 605 sustainability (CS) reports, including Circular Economy-flagged and non-flagged activities, and 606 considering the five categories: operations $(\mathrm{O})$, raw materials sourcing $(\mathrm{S})$, end-of-life (EoL), circular 607 design strategy (CD) and circular business models (CBM).

608

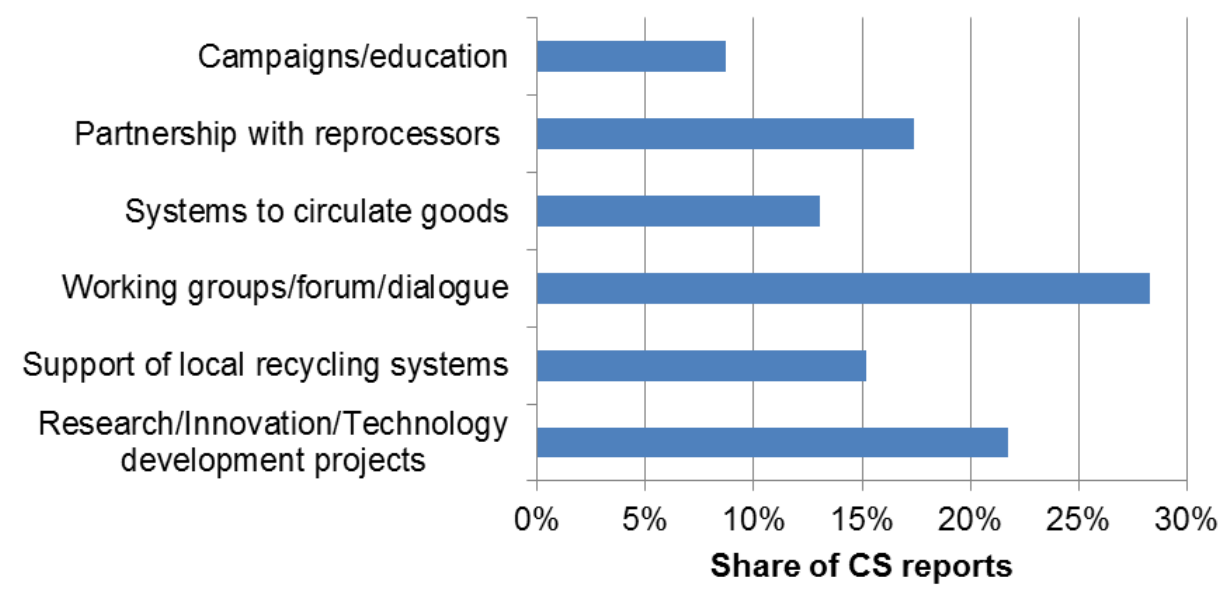

609

610 Figure 7. Summary of external collaboration types in the context of Circular Economy as reported in 611 the corporate sustainability (CS) reports. 
612

613

614

615

616

617

618

619

620

621

622

623

624

625

626

627

628

629

630

631

632

633

634

635

636

637

638

639

640

641

642

643

644

645

646

647

\section{References}

ADEME (2016) Intégration de l'économie circulaire dans la planification régionale et les démarches territoriales synergies, méthodes et recommandations. (English title: Integration of circular economy in regional planning and territorial initiatives: synergies, methods and recommendations) available at: http://www.ademe.fr/sites/default/files/assets/documents/integration-economie-circulaireplanification-regionale-201606-synthese.pdf

Aminoff, A, Valkokari, K, Kettunen, O. 2016. Mapping Multidimensional Value(s) for Co-creation Networks in a Circular Economy. In: IFIP Advances in Information and Communication Technology. Collaboration in a Hyperconnected World. PRO-VE 2016, Afsarmanesh H., Camarinha-Matos L., Lucas Soares A. (eds) vol 480. Springer International Publishing, Cham. doi: 10.1007/978-3-319-45390-3

Bengtsson, M. 2016. How to plan and perform a qualitative study using content analysis. NursingPlus Open 2:8-14. doi: 10.1016/j.npls.2016.01.001

Bjørn, A, Bey, N, Georg, S, Røpke, I, Hauschild, MZ. 2016. Is Earth recognized as a finite system in corporate responsibility reporting? Journal of Cleaner Production 163: 1-12. doi:10.1016/j.jclepro.2015.12.095

Blomsma, F, Brennan, G. 2017. The emergence of circular economy: a new framing around prolonging resource productivity. Journal of Industrial Ecology 21(3): 603-614. doi:10.1111/jiec.12603

Bocken, NMP, Bakker, C, Pauw, I De. 2016. Product design and business model strategies for a circular economy. Journal of Industrial and Production Engineering 33(5): 308-320. doi:10.1080/21681015.2016.1172124

Bocken, NMP, Ritala, P, Huotari, P. 2017. The Circular Economy: Exploring the Introduction of the Concept Among S\&P 500 Firms. Journal of Industrial Ecology 21(3): 487-490. doi:10.1111/jiec.12605

Borga, F, Citterio, A, Noci, G, Pizzurno, E. 2009. Sustainability report in small enterprises: Case studies in Italian furniture companies. Business Strategy and the Environment 18(3): 162-176. doi:10.1002/bse.561

CIRAIG, 2015. Circular economy: a critical literature review of concepts. Montréal,Québec, Canada. Available from http://www.ciraig.org/pdf/CIRAIG CircularEconomy Literature Review Oct2015.pdf.

Comas Martí, JM, Seifert, RW. 2013. Assessing the comprehensiveness of supply chain environmental strategies. Business Strategy and the Environment 22(5): 339-356. doi:10.1002/bse.1749

CR, 2017. About Reports. http://www.corporateregister.com/aboutreports.html [13 June 2017].

De los Rios, IC, Charnley, FJS. 2017. Skills and capabilities for a sustainable and circular economy: The changing role of design. Journal of Cleaner Production 160: 109-122. 
doi:10.1016/j.jclepro.2016.10.130

649

650

651

652

653

654

655

656

657

658

659

660

661

662

663

664

665

666

667

668

669

670

671

672

673

674

675

676

677

678

679

680

681

682

683

EC. 2014. Communication from the Commission to the European Parliament, the Council, the European Economic and Social Committee and the Committee of the Regions. Towards a circular economy: A zero waste programme for Europe. COM (2014) 398 final. Brussels.

EC. 2015. Communication from the Commission to the European Parliament, the Council, the European Economic and Social Committee and the Committee of the Regions. Closing the loop An EU action plan for the Circular Economy.COM (2015) 614. Brussels.

Elia, V, Gnoni, MG, Tornese, F. 2017. Measuring circular economy strategies through index methods: A critical analysis. Journal of Cleaner Production 142: 2741-2751. doi:10.1016/j.jclepro.2016.10.196

EMF. 2012. Towards the circular economy Vol.1. Economic and business rationale for an accelerated transition. Ellen MacArthur Foundation. Available at: https://www.ellenmacarthurfoundation.org/assets/downloads/publications/Ellen-MacArthurFoundation-Towards-the-Circular-Economy-vol.1.pdf

EMF. 2013. Towards the circular economy Vol.2. Opportunities for the consumer goods sector. Ellen MacArthur Foundation. Available at: https://www.ellenmacarthurfoundation.org/assets/downloads/publications/TCE_Report-2013.pdf

EMF. 2015. Growth within: A circular economy vision for a competitive Europe 100. Ellen MacArthur Foundation. Available at: https://www.ellenmacarthurfoundation.org/assets/downloads/publications/EllenMacArthurFounda tion_Growth-Within_July15.pdf

EMF, 2017a. CE100. Directory. https://www.ellenmacarthurfoundation.org/ce100/directory [13 June 2017].

EMF. 2017b. The new plastics economy. Ellen MacArthur Foundation. Available at: https://www.ellenmacarthurfoundation.org/assets/downloads/New-Plastics-Economy_CatalysingAction_13-1-17.pdf

Geissdoerfer, M, Savaget, P, Bocken, NMP, Hultink, EJ. 2017. The Circular Economy - a new sustainability paradigm? Journal of Cleaner Production 143: 757-768. doi:10.1016/j.jclepro.2016.12.048

Ghisellini, P, Cialani, C, Ulgiati, S. 2016. A review on circular economy: The expected transition to a balanced interplay of environmental and economic systems. Journal of Cleaner Production 114: 11-32. doi:10.1016/j.jclepro.2015.09.007

Goedkoop, M, Mieras, E, Gaasbeek, A, Contreras, S. 2015. How to Make the Life Cycle Assessment Team a Business Partner. In LCA Compendium - The Complete World of Life Cycle Assessment. Life Cycle Management, Sonnemann, G, Margni, M. (eds). Springer Netherlands. doi: 10.1007/978-94-017-7221-1 
684

685

686

687

688

689

690

691

692

693

694

695

696

697

698

699

700

701

702

703

704

705

706

707

708

709

710

711

712

713

714

715

716

717

718

Graneheim, UH, Lundman, B, 2004. Qualitative content analysis in nursing research: concepts, procedures and measures to achieve trustworthiness. Nurse Education Today 24(2):105-112. doi: 10.1016/j.nedt.2003.10.001

Grosso, M., Rigamonti, L., Niero, M. 2017. Circular economy, permanent materials and limitations to recycling: Where do we stand and what is the way forward? Waste Management and Research 35 (8): 793-794. doi: 10.1177/0734242X17724652

Hahn, R, Kühnen, M. 2013. Determinants of sustainability reporting: A review of results, trends, theory, and opportunities in an expanding field of research. Journal of Cleaner Production 59: 521. doi:10.1016/j.jclepro.2013.07.005

Haupt, M, Zschokke, M. 2017. How can LCA support the circular economy? 63rd discussion forum on life cycle assessment, Zurich, Switzerland, November 30, 2016. International Journal of Life Cycle Assessment 22(5): 832-837. doi:10.1007/s11367-017-1267-1

Hazen, BT, Mollenkopf, DA, Wang, Y. 2017. Remanufacturing for the Circular Economy: An Examination of Consumer Switching Behavior. Business Strategy and the Environment 26:451464. doi: 0.1002/bse.1929

Hrasky, S, 2011. Carbon footprints and legitimation strategies: symbolism or action? Accounting, Auditing \& Accountability Journal 25(1):174-198. doi: 10.1108/09513571211191798

Hsieh, HF, Shannon, SE, 2005. Three Approaches to Qualitative Content Analysis. Qualitative Health Research 15(9):1277-1288. doi: 10.1177/1049732305276687

Jones, P, Comfort, D. 2017. Towards the circular economy: A commentary on corporate approaches and challenges. Journal of Public Affairs 17(4): 1-5. doi: 10.1002/pa.1680

Kirchherr, J, Reike, D, Hekkert, M. 2017. Conceptualizing the circular economy: An analysis of 114 definitions. Resources, Conservation and Recycling 127: 221-232, doi:10.1016/j.resconrec.2017.09.005

Korhonen, J, Honkasalo, A, Seppälä, J. 2018. Circular Economy: The Concept and its Limitations. Ecological Economics 143: 37-46. doi:10.1016/j.ecolecon.2017.06.041

Kohlbacher, F, 2005. The Use of Qualitative Content Analsis in Case Study Research. Forum: Qualitative Social Research 7(1) http://nbn-resolving.de/urn:nbn:de:0114-fqs0601211

Kozlowski, A, Searcy, C, Bardecki, M, 2015. Corporate sustainability reporting in the apparel industry: An analysis of indicators disclosed. International Journal of Productivity and Performance Management 64(3):377-397. doi: 10.1108/IJPPM-10-2014-0152

Landrum, NE, Ohsowski, B. 2017. Identifying Worldviews on Corporate Sustainability: A Content Analysis of Corporate Sustainability Reports. Business Strategy and the Environment. doi: 10.1002/bse. 1989

Lewandowski, M. 2016. Designing the business models for circular economy-towards the conceptual 
Lieder, M., Rashid, A., 2016. Towards circular economy implementation: A comprehensive review in context of manufacturing industry. Journal of Cleaner Production 115: 36-51. doi:10.1016/j.jclepro.2015.12.042

Linder, M, Sarasini, S, van Loon, P. 2017. Metric for Quantifying Product-Level Circularity. Journal of Industrial Ecology 21(3): 545-558. doi: 10.1111/jiec.12552

Linder, M, Williander, M. 2017. Circular Business Model Innovation: Inherent Uncertainties. Business. Strategy and the Environment 26:182-196. doi: 10.1002/bse.1906

Manninen, K, Koskela, S, Antikainen, R, Bocken, N, Dahlbo, H, Aminoff, A. 2018. Do circular economy business models capture intended environmental value propositions? Journal of Cleaner Production 171:413-422. doi: 10.1016/j.jclepro.2017.10.003

McDonough, W, Braungart, M. 2002. Cradle to Cradle: Remaking the Way We Make Things. North Point Press: New York.

Meckenstock, J, Barbosa-Póvoa, AP, Carvalho, A. 2016. The Wicked Character of Sustainable Supply Chain Management: Evidence from Sustainability Reports. Business Strategy and the Environment 25(7): 449-477. doi:10.1002/bse.1872

Montabon, F, Sroufe, R, Narasimhan, R. 2007. An examination of corporate reporting, environmental management practices and firm performance. Journal of Operations Management 25(5): 9981014. doi:10.1016/j.jom.2006.10.003

Moreno, M, De los Rios, C, Rowe, Z, Charnley, F. 2016. A conceptual framework for circular design. Sustainability 8(9): doi:10.3390/su8090937

Murray, A, Skene, K, Haynes, K. 2015. The Circular Economy: An Interdisciplinary Exploration of the Concept and Application in a Global Context. Journal of Business Ethics 140(3): 369-380. doi:10.1007/s10551-015-2693-2

Niero, M, Hauschild, MZ, Hoffmeyer, SB, Olsen, SI. 2017. Combining Eco-Efficiency and EcoEffectiveness for Continuous Loop Beverage Packaging Systems: Lessons from the Carlsberg Circular Community. Journal of Industrial Ecology 21(3): 742-753. doi:10.1111/jiec.12554

Niero, M, Hauschild, MZ. 2017. Closing the loop for packaging: finding a framework to operationalize Circular Economy strategies. Procedia CIRP 61:685 - 690. doi: 10.1016/j.procir.2016.11.209

Niero, M, Negrelli, AJ, Boas, SH, Olsen, SI, Birkved, M. 2016. Closing the loop for aluminium cans: Life Cycle Assessment of progression in Cradle-to-Cradle certification levels. Journal of Cleaner Production 126: 352-362. doi:10.1016/j.jclepro.2016.02.122

Pauliuk, S. 2018. Critical appraisal of the circular economy standard BS 8001:2017 and a dashboard of quantitative system indicators for its implementation in organizations. Resources, Conservation and Recycling 129: 81-92. doi:10.1016/j.resconrec.2017.10.019 
Potting, J, Hekkert, M, Worrell, E, Hanemaaijer, A. 2016. Circular Economy: Measuring innovation in the product chains. PBL Netherlands Environmental Assessment Agency: The Hague.

Ranta, V, Aarikka-Senroos, L, Ritala, P, Mäkinen, SJ, 2017. Exploring institutional drivers and barriers of the circular economy: A cross-regional comparison of China, the US, and Europe. Resource Conservation and Recycling. doi: 10.1016/j.resconrec.2017.08.017

Ritzen, S, Sandström, GÖ. 2017. Barriers to the Circular Economy - integration of perspectives and domains. Procedia CIRP 64: 7 - 12. doi: 10.1016/j.procir.2017.03.005

Roca, LC, Searcy, C. 2012. An analysis of indicators disclosed in corporate sustainability reports. Journal of Cleaner Production 20: 103-118. doi:10.1016/j.jclepro.2011.08.002

Sauvé, S, Bernard, S, Sloan, P. 2016. Environmental sciences, sustainable development and circular economy: Alternative concepts for trans-disciplinary research. Environmental Development 17: 48-56. doi:10.1016/j.envdev.2015.09.002

Siew, RYJ. 2015. A review of corporate sustainability reporting tools (SRTs). Journal of Environmental Management 164 : 180-195. doi:10.1016/j.jenvman.2015.09.010

Sihvonen, S, Partanen, J. 2017. Eco-design practices with a focus on quantitative environmental targets: An exploratory content analysis within ICT sector. Journal of Cleaner Production 143: 769-783. doi:10.1016/j.jclepro.2016.12.047

Singh, J, Ordoñez, I. 2016. Resource recovery from post-consumer waste: important lessons for the upcoming circular economy. Journal of Cleaner Production 134A: 342-353. doi: 10.1016/j.jclepro.2015.12.020

Stahel, W. 2016. The circular economy. Nature 531:435-438. doi: 10.1038/531435a

Stewart, R, Niero M, Murdock, K, Olsen, SI. 2018. Exploring the implementation of a circular economy strategy: the case of a closed-loop supply of aluminum beverage cans. Accepted for publication in Procedia CIRP (November 2017).

Unilever. 2016. Unilever Sustainable Living Plan. Summary of Progress 2015. Mobilising Collective Action. Unilever Plc/NV.

Unilever, 2017. Rethinking waste - towards a circular economy. https://www.unilever.com/sustainable-living/reducing-environmental-impact/waste-andpackaging/rethinking-waste-towards-a-circular-economy/ [13 June 2017].

Webster, K. 2013. What Might We Say about a Circular Economy? Some Temptations to Avoid if Possible. World Futures, 69:542-554, doi:10.1080/02604027.2013.835977

Winans, K, Kendall, A, Deng, H. 2017. The history and current applications of the circular economy concept. Renewable and Sustainable Energy Reviews 68: 825-833. doi:10.1016/j.rser.2016.09.123

Witjes, S, Lozano, R. 2016. Towards a more Circular Economy: Proposing a framework linking 
sustainable public procurement and sustainable business models. Resources, Conservation and Recycling 112: 37-44. doi:10.1016/j.resconrec.2016.04.015

790 Young, CW, Russell, SV, Robinson, CA, Chintakayala, PK. 2017. Sustainable retailing - influencing consumer behaviour on food waste. Business Strategy and the Environment doi: 10.1002/bse.1966 


\begin{tabular}{|c|c|c|c|}
\hline Company name & Report name & Region & Sector \\
\hline Amcor Limited & $\begin{array}{l}\text { Sustainability Review 2016. Creating a new } \\
\text { world of packaging }\end{array}$ & Oceania & Packaging \\
\hline Asics Corporation & Sustainability Report 2015. We are Asics & Asia & $\begin{array}{l}\text { Household Goods \& } \\
\text { Textiles }\end{array}$ \\
\hline Ball Corporation & 2016 Sustainability Report & North America & Packaging \\
\hline $\begin{array}{l}\text { Barilla G e R } \\
\text { Fratelli SpA }\end{array}$ & Good for You, Good for the Planet 2016 Report & Europe & Food \& Beverage \\
\hline Bonduelle Groupe & Registration Document 2015-2016 & Europe & Food \& Beverage \\
\hline C\&A Global ${ }^{1}$ & $\begin{array}{l}\text { Global Sustainability Report } 2015 \text { Summary. } \\
\text { Material Impacts }\end{array}$ & Europe & $\begin{array}{l}\text { Household Goods \& } \\
\text { Textiles }\end{array}$ \\
\hline $\begin{array}{l}\text { Carlsberg } \\
\text { Breweries AS }\end{array}$ & Carlsberg Group Sustainability Report 2015 & Europe & Food \& Beverage \\
\hline $\begin{array}{l}\text { China Agri- } \\
\text { Industries } \\
\text { Holdings Limited }\end{array}$ & 2015 CSR Report & Asia & Food \& Beverage \\
\hline $\begin{array}{l}\text { Coca-Cola } \\
\text { Enterprises Inc } \\
\text { (CCE) }\end{array}$ & $\begin{array}{l}\text { Corporate Responsibility \& Sustainability } \\
\text { Report 2015/2016 }\end{array}$ & North America & Food \& Beverage \\
\hline $\begin{array}{l}\text { Colgate-Palmolive } \\
\text { Company }\end{array}$ & $\begin{array}{l}\text { Colgate Sustainability Report 2015. Giving the } \\
\text { World Reasons to Smile }\end{array}$ & North America & $\begin{array}{l}\text { Personal Care \& Household } \\
\text { Products }\end{array}$ \\
\hline $\begin{array}{l}\text { Dairy Crest Group } \\
\text { plc }\end{array}$ & Annual Report 2016. Going for Growth & Europe & Food \& Beverage \\
\hline Davines SpA & Sustainability Report Davines Group 2015 & Europe & $\begin{array}{l}\text { Personal Care \& Household } \\
\text { Products }\end{array}$ \\
\hline Diageo plc & Annual Report 2016 & Europe & Food \& Beverage \\
\hline Eco-Products & Sustainability Report 2016 & North America & $\begin{array}{l}\text { Household Goods \& } \\
\text { Textiles }\end{array}$ \\
\hline $\begin{array}{l}\text { Expresso Fashion } \\
\text { BV }\end{array}$ & Social Report [1st April 2015 31st March 2016] & Europe & $\begin{array}{l}\text { Household Goods \& } \\
\text { Textiles }\end{array}$ \\
\hline $\begin{array}{l}\text { Fromageries Bel } \\
\text { SA }\end{array}$ & $\begin{array}{l}2015 \text { Communication on Progress of the Bel } \\
\text { Group's CSR }\end{array}$ & Europe & Food \& Beverage \\
\hline Groupe Rocher & The Essentials of CSR 2015 & Europe & $\begin{array}{l}\text { Personal Care \& Household } \\
\text { Products }\end{array}$ \\
\hline Groupe SEB & $\begin{array}{l}2015 \text { Financial Report and Registration } \\
\text { Document }\end{array}$ & Europe & $\begin{array}{l}\text { Household Goods \& } \\
\text { Textiles }\end{array}$ \\
\hline Growmark Inc & $\begin{array}{l}\text { Corporate Responsibility Report 2016. Taking } \\
\text { Care. Paying Forward }\end{array}$ & North America & Food \& Beverage \\
\hline$H \& M^{2}$ & Sustainability Report 2015. Conscious Actions & Europe & $\begin{array}{l}\text { Household Goods \& } \\
\text { Textiles }\end{array}$ \\
\hline Heineken NV & $\begin{array}{l}\text { Sustainability Report 2015. Brewing a Better } \\
\text { World }\end{array}$ & Europe & Food \& Beverage \\
\hline IKEA AB & IKEA Group Sustainability Report FY16 & Europe & $\begin{array}{l}\text { Household Goods \& } \\
\text { Textiles }\end{array}$ \\
\hline Inditex SA & Annual Report 2015 & Europe & $\begin{array}{l}\text { Household Goods \& } \\
\text { Textiles }\end{array}$ \\
\hline $\begin{array}{l}\text { KappAhl Holding } \\
\mathrm{AB}\end{array}$ & KappAhl 2016 & Europe & $\begin{array}{l}\text { Household Goods \& } \\
\text { Textiles }\end{array}$ \\
\hline
\end{tabular}




\begin{tabular}{|c|c|c|c|}
\hline Company name & Report name & Region & Sector \\
\hline $\begin{array}{l}\text { Keurig Green } \\
\text { Mountain }\end{array}$ & Sustainability Report Fiscal Year 2015 & North America & Food \& Beverage \\
\hline Luigi Lavazza SpA & Sustainability Report 2015 & Europe & Food \& Beverage \\
\hline $\begin{array}{l}\text { LVMH-Moët } \\
\text { Hennessy Louis } \\
\text { Vuitton SA }\end{array}$ & LVMH 2015 Environmental Report & Europe & $\begin{array}{l}\text { Household Goods \& } \\
\text { Textiles }\end{array}$ \\
\hline $\begin{array}{l}\text { Marimekko } \\
\text { Corporation }\end{array}$ & Sustainability Review 2015 & Europe & $\begin{array}{l}\text { Household Goods \& } \\
\text { Textiles }\end{array}$ \\
\hline $\begin{array}{l}\text { Mayr-Melnhof } \\
\text { Karton AG }\end{array}$ & Annual Report 2015 & Europe & Packaging \\
\hline $\begin{array}{l}\text { Mohawk Industries } \\
\text { Inc }\end{array}$ & $\begin{array}{l}2015 \text { Corporate Responsibility \& Sustainability } \\
\text { Report }\end{array}$ & North America & $\begin{array}{l}\text { Household Goods \& } \\
\text { Textiles }\end{array}$ \\
\hline Nike Inc & $\begin{array}{l}\text { FY14/15 Sustainable Business Report. } \\
\text { Sustainable Innovation is a Powerful Engine for } \\
\text { Growth }\end{array}$ & North America & $\begin{array}{l}\text { Household Goods \& } \\
\text { Textiles }\end{array}$ \\
\hline Oy Karl Fazer AB & $\begin{array}{l}\text { Fazer Groups Corporate Responsibility Review } \\
2015\end{array}$ & Europe & Food \& Beverage \\
\hline Pepsico Inc & $\begin{array}{l}\text { Sustainability Report 2015. Performance with } \\
\text { Purpose. } 2025 \text { Agenda }\end{array}$ & North America & Food \& Beverage \\
\hline Pernod Ricard SA & Registration document 2015/2016 & Europe & Food \& Beverage \\
\hline $\begin{array}{l}\text { Procter \& Gamble } \\
\text { Inc }\end{array}$ & P\&G 2016 Citizenship Report & North America & $\begin{array}{l}\text { Personal Care \& Household } \\
\text { Products }\end{array}$ \\
\hline $\begin{array}{l}\text { RCL foods } \\
\text { Limited }\end{array}$ & $\begin{array}{l}\text { Our Sustainability Business Report for the Year } \\
\text { Ended } 30 \text { June } 2016\end{array}$ & Africa & Food \& Beverage \\
\hline SABMiller plc & Sustainable Development Report 2016 & Europe & Food \& Beverage \\
\hline $\begin{array}{l}\text { Scottish Leather } \\
\text { Group Limited }\end{array}$ & $\begin{array}{l}\text { Group Sustainability Report Year ending 31st } \\
\text { March } 2015\end{array}$ & Europe & $\begin{array}{l}\text { Household Goods \& } \\
\text { Textiles }\end{array}$ \\
\hline Sealed Air Corp & Sustainability Report Issued 2016 & North America & Packaging \\
\hline $\begin{array}{l}\text { Shaw Industries } \\
\text { Group Inc }\end{array}$ & Sustainability Report 2015 & North America & $\begin{array}{l}\text { Household Goods \& } \\
\text { Textiles }\end{array}$ \\
\hline Société BIC & $\begin{array}{l}2015 \text { Sustainable Development Report. Made to } \\
\text { Last }\end{array}$ & Europe & $\begin{array}{l}\text { Household Goods \& } \\
\text { Textiles }\end{array}$ \\
\hline $\begin{array}{l}\text { Svenska Cellulosa } \\
\text { Aktiebolaget } \mathrm{AB}^{1}\end{array}$ & Sustainability Report 2015 & Europe & $\begin{array}{l}\text { Personal Care \& Household } \\
\text { Products }\end{array}$ \\
\hline Tarkett SA & $\begin{array}{l}2015 \text { Activity \& Sustainability Report. } \\
\text { Committed to Better Living Spaces } \\
\end{array}$ & Europe & $\begin{array}{l}\text { Household Goods \& } \\
\text { Textiles }\end{array}$ \\
\hline Tetra Pak Group & $\begin{array}{l}\text { Sustainability Update 2016. Food. People. } \\
\text { Future }\end{array}$ & Europe & Packaging \\
\hline $\begin{array}{l}\text { Thimm Holding } \\
\text { Gmbh \& Co Kg }\end{array}$ & $\begin{array}{l}\text { Sustainability Report 2016. People, Ideas, } \\
\text { Solutions }\end{array}$ & Europe & Packaging \\
\hline Åhléns AB & Sustainability Report 2015 & Europe & $\begin{array}{l}\text { Household Goods \& } \\
\text { Textiles }\end{array}$ \\
\hline
\end{tabular}

795 Textile and Flooring" of the CE100 directory (https://www.ellenmacarthurfoundation.org/ce100/directory)

$796{ }^{2}$ Report added to the sample since the company is a founding company of the EMF and belongs to the textile industry

797 Table A1: List of reviewed corporate sustainability reports, including company name, report name, 798 region where the headquarters are registered and sector of activity. All subsidiaries' reports that had 799 featured the list were excluded, thus the focus is solely on mother companies. 


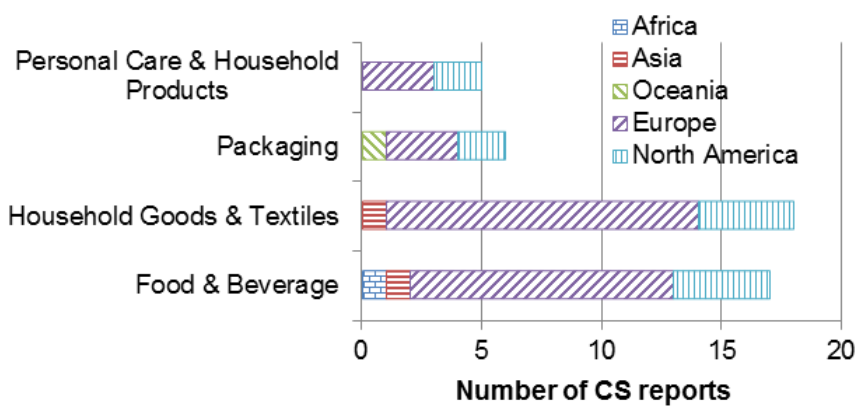

800

801 Figure A1. Regional and sectoral distribution of CS reports in the sample.

802

\begin{tabular}{|l|l|}
\hline Principle & Keywords \\
\hline Reduce & Rethink, re-think, refus, redesign, re-design, minimiz, minimis, prolong, extend $^{*}$, \\
\hline Reuse & Reus, repurpos, refurbish, repair, second life, maintain \\
\hline Recycle & Recycl, remanufactur \\
\hline Recover & Recover \\
\hline
\end{tabular}

*In italics are keyword added inductively from the data.

804 Table A2. List of keywords used in RQ1 based on Kirchherr et al. (2017)

805

\begin{tabular}{|l|l|}
\hline Category & Definition \\
\hline Systemic dimension & $\begin{array}{l}\text { CE is mentioned in relation with the need for a shift/radical change/transition away from } \\
\text { today's system (economy, sector, business). }\end{array}$ \\
\hline General statement & CE is mentioned in a general descriptive, normative, aspirational statement. \\
\hline Concrete activities & CE is associated to concrete undertakings internally or externally. \\
\hline Beneficial linkage & $\begin{array}{l}\text { CE is considered as one way to progress towards sustainability among others. (Geissdoerfer } \\
\text { et al., 2017) }\end{array}$ \\
\hline Conditional linkage & CE is considered as a condition for reaching sustainability. (Geissdoerfer et al., 2017) \\
\hline Tradeoff linkage & $\begin{array}{l}\text { CE is considered to lead to sustainability trade-offs (both benefits and negative outcomes). } \\
\text { (Geissdoerfer et al., 2017) }\end{array}$ \\
\hline
\end{tabular}

Table A3. Overview of coding categories for RQ1 and RQ2.

807

808

809

810

811 


\begin{tabular}{|c|c|}
\hline Categories & Definition \\
\hline Recycled content (S) & The company reports using recycled material in its products \\
\hline Renewable material (S) & The company reports using material from renewable sources in its products \\
\hline Energy efficiency $(\mathrm{O})$ & The company indicates adopting measures to save energy \\
\hline Renewable energy $(\mathrm{O})$ & The company indicates using energy from renewable sources \\
\hline Recovery of operation waste $(\mathrm{O})$ & $\begin{array}{l}\text { The company reports measures for reusing/recycling the waste/byproducts it } \\
\text { produces in its operations }\end{array}$ \\
\hline $\begin{array}{l}\text { Supporting recycling/recovery } \\
\text { infrastructure/initiatives (funding, } \\
\text { campaign, research) (EoL) }\end{array}$ & The company indicates measures to support the recycling system \\
\hline $\begin{array}{l}\text { Design for closing resource loops } \\
\text { (CD) }\end{array}$ & $\begin{array}{l}\text { Design for biodegradability, Design with healthy/smart processes/materials } \\
\text { (Moreno et al., 2016) }\end{array}$ \\
\hline $\begin{array}{l}\text { Design for reduce resource } \\
\text { consumption }(\mathrm{CD})\end{array}$ & $\begin{array}{l}\text { Design with healthy/smart processes/materials; Design for reduction of production } \\
\text { step; Design for light weighting, miniaturizing; Design for eliminating yield } \\
\text { loses/material/resources/parts/packaging; Design for reducing material/resource use } \\
\text { (Moreno et al., 2016) }\end{array}$ \\
\hline $\begin{array}{l}\text { Design for reliability \& durability } \\
\text { (CD) }\end{array}$ & $\begin{array}{l}\text { Design on demand or on availability; Design the appropriate lifespan of } \\
\text { products/components (Moreno et al., 2016) }\end{array}$ \\
\hline $\begin{array}{l}\text { Design for product attachment \& } \\
\text { trust }(C D)\end{array}$ & $\begin{array}{l}\text { Create timeless aesthetics; Design for pleasurable experiences; Meaningful design } \\
\text { (Moreno et al., 2016) }\end{array}$ \\
\hline $\begin{array}{l}\text { Design for extending product life } \\
\text { (CD) }\end{array}$ & $\begin{array}{l}\text { Design for repair/refurbishment; Design for easy maintenance, reuse and repair; } \\
\text { Design for upgradability and flexibility (Moreno et al., 2016) }\end{array}$ \\
\hline $\begin{array}{l}\text { Design for dematerialization of } \\
\text { products }(\mathrm{CD})\end{array}$ & $\begin{array}{l}\text { Design for product-service systems; Design for swapping, renting and sharing. } \\
\text { (Moreno et al., 2016) }\end{array}$ \\
\hline Design for resource recovery (CD) & $\begin{array}{l}\text { Design for easy end-of-life cleaning, collection and transportation of recovered } \\
\text { material/resources; Design for cascade use; Design for (re)manufacturing and dis- } \\
\text { and re-assembly; Design for upcycling/recycling (Moreno et al., 2016) }\end{array}$ \\
\hline $\begin{array}{l}\text { Design to reduce environmental } \\
\text { backpacks }(\mathrm{CD})\end{array}$ & $\begin{array}{l}\text { Design for the entire value chain; Design for local value chains (Moreno et al., } \\
\text { 2016) }\end{array}$ \\
\hline $\begin{array}{l}\text { Design for regenerative systems } \\
\text { (CD) }\end{array}$ & $\begin{array}{l}\text { Design for biomimicry; Design for biological and technical cycles (Moreno et al., } \\
\text { 2016) }\end{array}$ \\
\hline Circular supplies (CBM) & $\begin{array}{l}\text { "A business model based on industrial symbiosis in which the residual outputs from } \\
\text { one process can be used as feedstock for another process" (Moreno et al., 2016) }\end{array}$ \\
\hline Resource value (CBM) & $\begin{array}{l}\text { "A business model based on recovering the resource value of materials and } \\
\text { resources to be used in new forms of value" (Moreno et al., 2016) }\end{array}$ \\
\hline Product life extension $(\mathrm{CBM})$ & $\begin{array}{l}\text { "Those business models that are based on extending the working life of a product" } \\
\text { (Moreno et al., 2016) }\end{array}$ \\
\hline Extending product value (CBM) & $\begin{array}{l}\text { "Those business models based on offering product access and retaining } \\
\text { ownership to internalize benefits of circular resource productivity" (Moreno et al., } \\
\text { 2016) }\end{array}$ \\
\hline Sharing platforms (CBM) & $\begin{array}{l}\text { "Those business models that enable increased utilization rates of products by } \\
\text { making possible shared use/access/ownership (Moreno et al., 2016) }\end{array}$ \\
\hline
\end{tabular}

812 Table A4. Overview of mapping framework for CE-related activities (RQ3), adapted from Moreno et

813 al., (2016). $\mathrm{S}=$ sourcing. $\mathrm{O}=$ operations. EoL=End-of-life. $\mathrm{CD}=$ circular design. $\mathrm{CBM}=$ circular business

814 model. 


\begin{tabular}{|c|c|}
\hline Company name & Extract coded for "systemic dimension of CE" \\
\hline Amcor & $\begin{array}{l}\text { "With an explicitly systemic and collaborative approach, the initiative aims to advance the plastics } \\
\text { value chain into a virtuous cycle of value capture, stronger economics, and better environmental } \\
\text { outcomes" (Amcor, 2016) }\end{array}$ \\
\hline C\&A & $\begin{array}{l}\text { "We want to help lead the fashion industry away from the make, use, dispose economy to one that } \\
\text { allows us to keep resources in use for as long as possible." (C\&A, 2016) }\end{array}$ \\
\hline $\begin{array}{l}\text { Carlsberg } \\
\text { Breweries }\end{array}$ & $\begin{array}{l}\text { "Resources and products should be designed and used in continuous resource loops. The only long- } \\
\text { term sustainable answer to waste is to reduce and, ultimately, eliminate it." (Carlsberg Breweries, } \\
\text { 2016) }\end{array}$ \\
\hline CCE & $\begin{array}{l}\text { "We are very clear that our economy cannot continue in its current take-make-dispose model and we } \\
\text { need to transform to a circular economy model" (CCE, 2016) }\end{array}$ \\
\hline Davines & $\begin{array}{l}\text { "All these signs are telling us that the future lies in a circular economy. Unlike the old linear system, } \\
\text { the new model is based on ethical and sustainable development, thanks to re-use and minimising } \\
\text { waste. A circle has no beginning and no end, and therefore can renew itself, assuring the future of } \\
\text { generations to come." (Davines, 2016) }\end{array}$ \\
\hline Eco-products & $\begin{array}{l}\text { "At the end of the day, everything comes back to waste diversion for us. It's our reason for being and } \\
\text { it is reflected in our new mission statement that you will find if you keep reading. Compostable } \\
\text { foodservice packaging is at its best when it enables the diversion of food scraps and other organic } \\
\text { material from landfills. In order for that to happen, there has to be a systems approach that takes into } \\
\text { account all inputs, incorporates a consistent communications strategy, and integrates with the haulers } \\
\text { and facilities who will accept the material and turn it into an ecologically essential and economically } \\
\text { valuable product. That is starting to sound like the kind of circular economy we want to be a part of." } \\
\text { (Eco-Products, 2016) }\end{array}$ \\
\hline Groupe SEB & $\begin{array}{l}\text { "Circular economy requires an approach of fitting of channels (e.g. recycling, reuse...). This } \\
\text { economic system is based on exchanges and production. At every stage of the life cycle of the } \\
\text { products, goods and services, it aims to increase the efficiency of the resources and to reduce the } \\
\text { impact on the environment while enabling the welfare of the individuals." (Groupe SEB, 2016) }\end{array}$ \\
\hline $\mathrm{H} \& \mathrm{M}$ & $\begin{array}{l}\text { "We want to move towards a } 100 \% \text { circular business model. This means nothing less than completely } \\
\text { turning around how our industry has been operating for decades - moving away from a linear } \\
\text { production model to one that uses once-created products as the resource for new desirable fashion." } \\
\text { (H\&M, 2016) }\end{array}$ \\
\hline Heineken & $\begin{array}{l}\text { "There is increasing focus on how businesses can move from a linear value chain model towards a } \\
\text { Circular Economy in which products and resources are reused or refurbished as part of new product } \\
\text { life-cycles." (Heineken, 2016) }\end{array}$ \\
\hline IKEA & $\begin{array}{l}\text { "Transitioning to a circular economy. Take make dispose. That's the model our economy is based on. } \\
\text { But it's not sustainable." (IKEA, 2016) }\end{array}$ \\
\hline KappAhl & $\begin{array}{l}\text { "We have also joined phase two of the Mistra Future Fashion programme that aims to create } \\
\text { conditions for a circular economy in the fashion industry." (KappAhl, 2016) }\end{array}$ \\
\hline Nike & $\begin{array}{l}\text { "We envision a transition from linear to circular business models and a world that demands closed- } \\
\text { loop products - designed with better materials, made with fewer resources and assembled to allow } \\
\text { easy reuse in new products." (Nike, 2016) }\end{array}$ \\
\hline SABMiller & $\begin{array}{l}\text { "In working towards the ambitious new climate goals, society needs to move to a more efficient, } \\
\text { circular economy focused on eliminating waste and emissions and creating value from what } \\
\text { remains." (SABMiller, 2016) }\end{array}$ \\
\hline SCA & $\begin{array}{l}\text { "In } 2015 \text {, the EU Commission presented its circular economy strategy that will lead to societal } \\
\text { change in many areas. SCA recognizes the need for solutions that drive the circular economy and } \\
\text { actively applies this thinking to all of its products." (SCA, 2016) }\end{array}$ \\
\hline Tarkett & $\begin{array}{l}\text { "CONTRIBUTING TO A CIRCULAR ECONOMY Tarkett is committed to the transition from a } \\
\text { linear to a circular economy model, which consists of recycling resources in a loop from the design } \\
\text { and production phases to later use and recovery stages." And "A key element of our approach is our } \\
\text { longstanding commitment to the circular economy. As we move away from a linear economy that } \\
\text { depletes finite resources, we take advantage of all opportunities to select materials that are good for } \\
\text { people's health and the environment, and recycle and reuse our products or materials from other }\end{array}$ \\
\hline
\end{tabular}




\begin{tabular}{|l|l|}
\hline & industries." (Tarkett, 2016) \\
\hline Tetra Pak & $\begin{array}{l}\text { "We have also signed up to the CE100, an innovative programme set up by the Ellen MacArthur } \\
\text { Foundation to support the long-term development of a circular economy: one that is restorative and } \\
\text { regenerative by design. (Tetra Pak, 2016) }\end{array}$ \\
\hline Åhlens & $\begin{array}{l}\text { "We have also asked ourselves: what role can Åhléns play in a future society based on a circular } \\
\text { economy?" (Åhlens, 2016) }\end{array}$ \\
\hline
\end{tabular}

Table A5. Coding results for the systemic dimension addressed in RQ1.

\begin{tabular}{|c|c|c|}
\hline Company name & Linkage & Extract \\
\hline Carlsberg Breweries & Conditional & $\begin{array}{l}\text { "Resources and products should be designed and used in continuous resource } \\
\text { loops. The only long-term sustainable answer to waste is to reduce and, } \\
\text { ultimately, eliminate it." (Carlsberg Breweries, 2016) }\end{array}$ \\
\hline Colgate-Palmolive & Conditional & $\begin{array}{l}\text { "Building a circular economy in which industrial materials and packaging can be } \\
\text { recycled and reused is an important part of a sustainable future." (Colgate- } \\
\text { Palmolive, 2016) }\end{array}$ \\
\hline Davines & Conditional & $\begin{array}{l}\text { "All these signs are telling us that the future lies in a circular economy. Unlike the } \\
\text { old linear system, the new model is based on ethical and sustainable development, } \\
\text { thanks to re-use and minimising waste. A circle has no beginning and no end, and } \\
\text { therefore can renew itself, assuring the future of generations to come." (Davines, } \\
\text { 2016) }\end{array}$ \\
\hline $\mathrm{H} \& \mathrm{M}$ & Conditional & $\begin{array}{l}\text { "The fashion industry is using more resources than the planet allows. As demand } \\
\text { increases, so will waste, pollution and carbon emissions while resources will } \\
\text { become increasingly scarce. Moving towards a circular model will be key for our } \\
\text { future success and growth. This is why we are currently working to update our } \\
\text { sustainability strategy." (H\&M, 2016) }\end{array}$ \\
\hline IKEA & Conditional & $\begin{array}{l}\text { "Transitioning to a circular economy. Take make dispose. That's the model our } \\
\text { economy is based on. But it's not sustainable." (IKEA, 2016) }\end{array}$ \\
\hline Barilla & Beneficial & $\begin{array}{l}\text { "Promote cooperation with farmers to make the agricultural sector more } \\
\text { sustainable according to circular economy models" (Barilla, 2016) }\end{array}$ \\
\hline Growmark & Beneficial & $\begin{array}{l}\text { "Our dedication to sustainable measures is not limited to the land. In business, we } \\
\text { look for opportunities that have impact far beyond our core purpose and that } \\
\text { support a circular economy." (Growmark, 2016) }\end{array}$ \\
\hline Inditex & Beneficial & $\begin{array}{l}\text { "In } 2015 \text { we also made progress towards the circular economy model with the } \\
\text { Closing the Loop project, which combines environmental and social sustainability } \\
\text { to pursue the goal of ensuring no used textile item ends up in landfill." (Inditex, } \\
\text { 2016) }\end{array}$ \\
\hline Luigi Lavazza & Beneficial & $\begin{array}{l}\text { "This served as an opportunity for Lavazza to confirm its commitment that sees it } \\
\text { involved in an intense activity of research and innovation aimed at developing } \\
\text { sustainable solutions that are inspired by the philosophy of a circular economy." } \\
\text { (Luigi Lavazza, 2016) }\end{array}$ \\
\hline Tarkett & Beneficial & $\begin{array}{l}\text { "We innovate by developing technology and specific designs to improve people's } \\
\text { well-being, for example by contributing to indoor air quality, by creating an } \\
\text { inspiring colorful environment and by improving sound control in living spaces. } \\
\text { Our eco-innovations based on healthy materials and our recycling model } \\
\text { contribute to our vision of a sustainable and profitable development. This } \\
\text { commitment to the circular economy is beneficial for society and the planet, as } \\
\text { well as improving our teams' pride and motivation." (Tarkett, 2016) }\end{array}$ \\
\hline
\end{tabular}




\begin{tabular}{|c|c|c|c|c|c|}
\hline \multirow[b]{2}{*}{ Research question } & \multirow{2}{*}{$\begin{array}{l}\text { FULL } \\
\text { SAMPLE }\end{array}$} & \multicolumn{2}{|c|}{ SECTORS } & \multicolumn{2}{|c|}{ REGIONS } \\
\hline & & HGT & FB & Europe & North America \\
\hline RQ1: & \multicolumn{5}{|c|}{ Share of reports } \\
\hline \multicolumn{6}{|l|}{ "R" principles } \\
\hline Reduce & $35 \%$ & $41 \%$ & $29 \%$ & $37 \%$ & $25 \%$ \\
\hline Reuse & $46 \%$ & $53 \%$ & $41 \%$ & $47 \%$ & $50 \%$ \\
\hline Recycle & $59 \%$ & $71 \%$ & $29 \%$ & $57 \%$ & $58 \%$ \\
\hline Recover & $20 \%$ & $18 \%$ & $35 \%$ & $20 \%$ & $25 \%$ \\
\hline \multicolumn{6}{|l|}{ Systemic dimension } \\
\hline Presence of systemic dimension & $37 \%$ & $47 \%$ & $24 \%$ & $43 \%$ & $25 \%$ \\
\hline \multicolumn{6}{|l|}{ Level of implementation } \\
\hline Concrete activity(ies) & $76 \%$ & $88 \%$ & $71 \%$ & $80 \%$ & $67 \%$ \\
\hline Only general statements & $24 \%$ & $12 \%$ & $29 \%$ & $20 \%$ & $33 \%$ \\
\hline \multicolumn{6}{|l|}{ RQ2 } \\
\hline \multicolumn{6}{|l|}{ Linkage } \\
\hline Conditional & $13 \%$ & $12 \%$ & $12 \%$ & $13 \%$ & $17 \%$ \\
\hline Beneficial & $11 \%$ & $6 \%$ & $18 \%$ & $13 \%$ & $8 \%$ \\
\hline Unclear & $76 \%$ & $82 \%$ & $71 \%$ & $73 \%$ & $75 \%$ \\
\hline \multicolumn{6}{|l|}{ Sustainability aspects } \\
\hline Environmental & $48 \%$ & $41 \%$ & $47 \%$ & $57 \%$ & $33 \%$ \\
\hline Economic & $28 \%$ & $12 \%$ & $41 \%$ & $23 \%$ & $33 \%$ \\
\hline Social & $7 \%$ & $6 \%$ & $0 \%$ & $10 \%$ & $0 \%$ \\
\hline \multicolumn{6}{|l|}{ RQ3 } \\
\hline \multicolumn{6}{|l|}{ Application system } \\
\hline Main product & $50 \%$ & $67 \%$ & $18 \%$ & $47 \%$ & $58 \%$ \\
\hline Packaging & $46 \%$ & $28 \%$ & $71 \%$ & $47 \%$ & $42 \%$ \\
\hline By-products & $24 \%$ & $17 \%$ & $41 \%$ & $33 \%$ & $0 \%$ \\
\hline \multicolumn{6}{|l|}{ Nutrient cycles } \\
\hline Both & $35 \%$ & $17 \%$ & $59 \%$ & $43 \%$ & $17 \%$ \\
\hline Only biological & $4 \%$ & $0 \%$ & $12 \%$ & $3 \%$ & $0 \%$ \\
\hline Only technical & $57 \%$ & $78 \%$ & $24 \%$ & $50 \%$ & $75 \%$ \\
\hline \multicolumn{6}{|l|}{ CE-related activities } \\
\hline Recycled content (S) & $50 \%$ & $61 \%$ & $41 \%$ & $47 \%$ & $67 \%$ \\
\hline Renewable material (S) & $46 \%$ & $50 \%$ & $35 \%$ & $50 \%$ & $33 \%$ \\
\hline Energy efficiency $(\mathrm{O})$ & $87 \%$ & $94 \%$ & $82 \%$ & $87 \%$ & $92 \%$ \\
\hline Renewable energy $(\mathrm{O})$ & $87 \%$ & $89 \%$ & $82 \%$ & $90 \%$ & $83 \%$ \\
\hline Recovery of operation waste $(\mathrm{O})$ & $65 \%$ & $56 \%$ & $76 \%$ & $63 \%$ & $75 \%$ \\
\hline $\begin{array}{l}\text { Supporting recycling/recovery infrastructure/initiatives } \\
\text { (EoL) }\end{array}$ & $50 \%$ & $39 \%$ & $53 \%$ & $47 \%$ & $67 \%$ \\
\hline Design for closing resource loops (CD) & $11 \%$ & $11 \%$ & $12 \%$ & $10 \%$ & $17 \%$ \\
\hline Design for reduce resource consumption (CD) & $43 \%$ & $28 \%$ & $59 \%$ & $30 \%$ & $75 \%$ \\
\hline Design for reliability \& durability (CD) & $13 \%$ & $22 \%$ & $6 \%$ & $13 \%$ & $17 \%$ \\
\hline Design for product attachment $\&$ trust (CD) & $0 \%$ & $0 \%$ & $0 \%$ & $0 \%$ & $0 \%$ \\
\hline Design for extending product life (CD) & $15 \%$ & $33 \%$ & $6 \%$ & $10 \%$ & $25 \%$ \\
\hline Design for dematerialization of products (CD) & $0 \%$ & $0 \%$ & $0 \%$ & $0 \%$ & $0 \%$ \\
\hline Design for resource recovery (CD) & $35 \%$ & $33 \%$ & $35 \%$ & $27 \%$ & $58 \%$ \\
\hline Design to reduce environmental backpack (CD) & $0 \%$ & $0 \%$ & $0 \%$ & $0 \%$ & $0 \%$ \\
\hline Design for regenerative systems (CD) & $7 \%$ & $11 \%$ & $6 \%$ & $7 \%$ & $8 \%$ \\
\hline Circular supplies (CBM) & $11 \%$ & $11 \%$ & $18 \%$ & $13 \%$ & $8 \%$ \\
\hline Product life extension (CBM) & $17 \%$ & $44 \%$ & $0 \%$ & $23 \%$ & $8 \%$ \\
\hline Extending product value (CBM) & $4 \%$ & $11 \%$ & $0 \%$ & $7 \%$ & $0 \%$ \\
\hline
\end{tabular}




\begin{tabular}{|l|l|l|l|l|l|}
\hline Collaboration practices & & & & & \\
\hline Research/Innovation/Technology development projects & $22 \%$ & $22 \%$ & $18 \%$ & $23 \%$ & $17 \%$ \\
\hline Support of local recycling systems & $15 \%$ & $0 \%$ & $24 \%$ & $3 \%$ & $42 \%$ \\
\hline Working groups/forum/dialogue & $28 \%$ & $39 \%$ & $18 \%$ & $30 \%$ & $25 \%$ \\
\hline Systems to circulate goods & $13 \%$ & $33 \%$ & $0 \%$ & $17 \%$ & $0 \%$ \\
\hline Sourcing partnership with reprocessors & $17 \%$ & $33 \%$ & $6 \%$ & $17 \%$ & $25 \%$ \\
\hline Campaigns/education & $9 \%$ & $6 \%$ & $12 \%$ & $7 \%$ & $17 \%$ \\
\hline
\end{tabular}

821 Table A7. Overview of results for RQ1-3 with sectoral and regional differentiation. With regard to the

822 sectors, we only provide the results for the Food \& Beverage (FB) and the Household Goods \&

823 Textiles (HGT) sector since Packaging and Personal Goods and Household Products are very limitedly

824 represented in the sample. Similarly, with regard to the regions, we only provide the results for Europe 825 and North America. 